\title{
Neutrophil-to-lymphocyte ratio as prognostic indicator in gastrointestinal cancers: a systematic review and meta-analysis
}

\author{
Randy C. Bowen ${ }^{1}$, Nancy Ann B. Little ${ }^{1}$, Joshua R. Harmer ${ }^{1}$, Junjie Ma², Luke G. \\ Mirabelli ${ }^{1}$, Kyle D. Roller ${ }^{1}$, Andrew Mackay Breivik ${ }^{1}$, Emily Signor ${ }^{1}$, Alec B. Miller ${ }^{1}$ \\ and Hung T. Khong ${ }^{1}$ \\ 1 Department of Oncology, University of Utah, Salt Lake City, Utah, USA \\ 2 Department of Pharmacotherapy, University of Utah, Salt Lake City, Utah, USA \\ Correspondence to: Hung T. Khong, email: hung.khong@hci.utah.edu \\ Keywords: neutrophil-to-lymphocyte ratio, gastrointestinal cancers, prognostic indicator, overall survival, biomarkers \\ Received: August 19, 2016 \\ Accepted: February 20, 2017 \\ Published: March 16, 2017 \\ Copyright: Bowen et al. This is an open-access article distributed under the terms of the Creative Commons Attribution License (CC-BY), \\ which permits unrestricted use, distribution, and reproduction in any medium, provided the original author and source are credited.
}

\section{ABSTRACT}

An accurate, time efficient, and inexpensive prognostic indicator is needed to reduce cost and assist with clinical decision making for cancer management. The neutrophil-to-lymphocyte ratio (NLR), which is derived from common serum testing, has been explored in a variety of cancers. We sought to determine its prognostic value in gastrointestinal cancers and performed a meta-analysis of published studies using the Meta-analysis Of Observational Studies in Epidemiology guidelines. Included were randomized control trials and observational studies that analyzed humans with gastrointestinal cancers that included NLR and hazard ratios (HR) with overall survival (OS), disease-free survival (DFS), progression-free survival (PFS), and/or cancerspecific survival (CSS).

We analyzed 144 studies comprising 45,905 patients, two-thirds of which were published after 2014. The mean, median, and mode cutoffs for NLR reporting OS from multivariate models were 3.4, 3.0, 5.0 ( \pm IQR 2.5-5.0), respectively. Overall, NLR greater than the cutoff was associated with a HR for OS of 1.63 (95\% CI, 1.53-1.73; P $<0.001$ ). This association was observed in all subgroups based on tumor site, stage, and geographic region. HR for elevated NLR for DFS, PFS, and CSS were 1.70 (95\% $C I, 1.52-1.91, P<0.001), 1.64$ (95\% CI, 1.36-1.97, $P<0.001)$, and 1.83 (95\% CI, 1.50-2.23, $P<0.001$ ), respectively.

Available evidence suggests that NLR greater than the cutoff reduces OS, independent of geographic location, gastrointestinal cancer type, or stage of cancer. Furthermore, DFS, PFS, and CSS also have worse outcomes with elevated NLR.

\section{INTRODUCTION}

As the genomic revolution advances, more molecular biomarkers have been discovered that can serve as druggable targets or prognosticators of therapeutic efficacy, disease recurrence, or survival. Though exciting to provide these novel options for patients, the cost of employing these molecular markers and the time to send off and obtain results can be significant. Therefore, even in this day of genomic and proteomic advancements, a simple, inexpensive and readily available prognostic marker is still highly desirable.
One of the simplest and most readily available tests in the clinic is the complete blood cell count (CBC), which reports the absolute neutrophil count (ANC) and absolute lymphocyte count (ALC). The neutrophil-to-lymphocyte ratio (NLR), calculated by dividing the ANC by the ALC, can serve as an index of systemic inflammatory response in critically ill patients [1]. The microenvironments of inflammation, created by mediators and cellular effectors, are recognized as both a condition that leads to cancer development, as well as an outcome that results from cancer cell growth [2]. Building on the six classic hallmarks of cancer, tumor-promoting inflammation is now widely accepted as an enabling characteristic, 
which supports multiple cancer hallmark capabilities [3]. Therefore, NLR may help to reflect systemic inflammation in patients with cancer and their immunologic capacity to mount an attack against the malignant cells. An increasing number of recent reports suggest that NLR can be used as a prognostic marker in various malignancies.

This meta-analysis aims to determine the prognostic value of NLR in gastrointestinal (GI) cancers for overall survival (OS), disease free survival (DFS), progression free survival (PFS), and cancer-specific survival (CSS).

\section{RESULTS}

We identified 4,594 articles of which 372 were selected for full-text review (Figure 1). 143 articles met the inclusion criteria, of which 141 were retrospective cohort studies, one was a retrospective case control study, and one was a prospective RCT. One article included 2 cancer site studies [4], resulting in 144 cancer site studies. Publication dates ranged from 2008 to 2016 with more than two-thirds published after 2014. A total of 118, 53, 10,

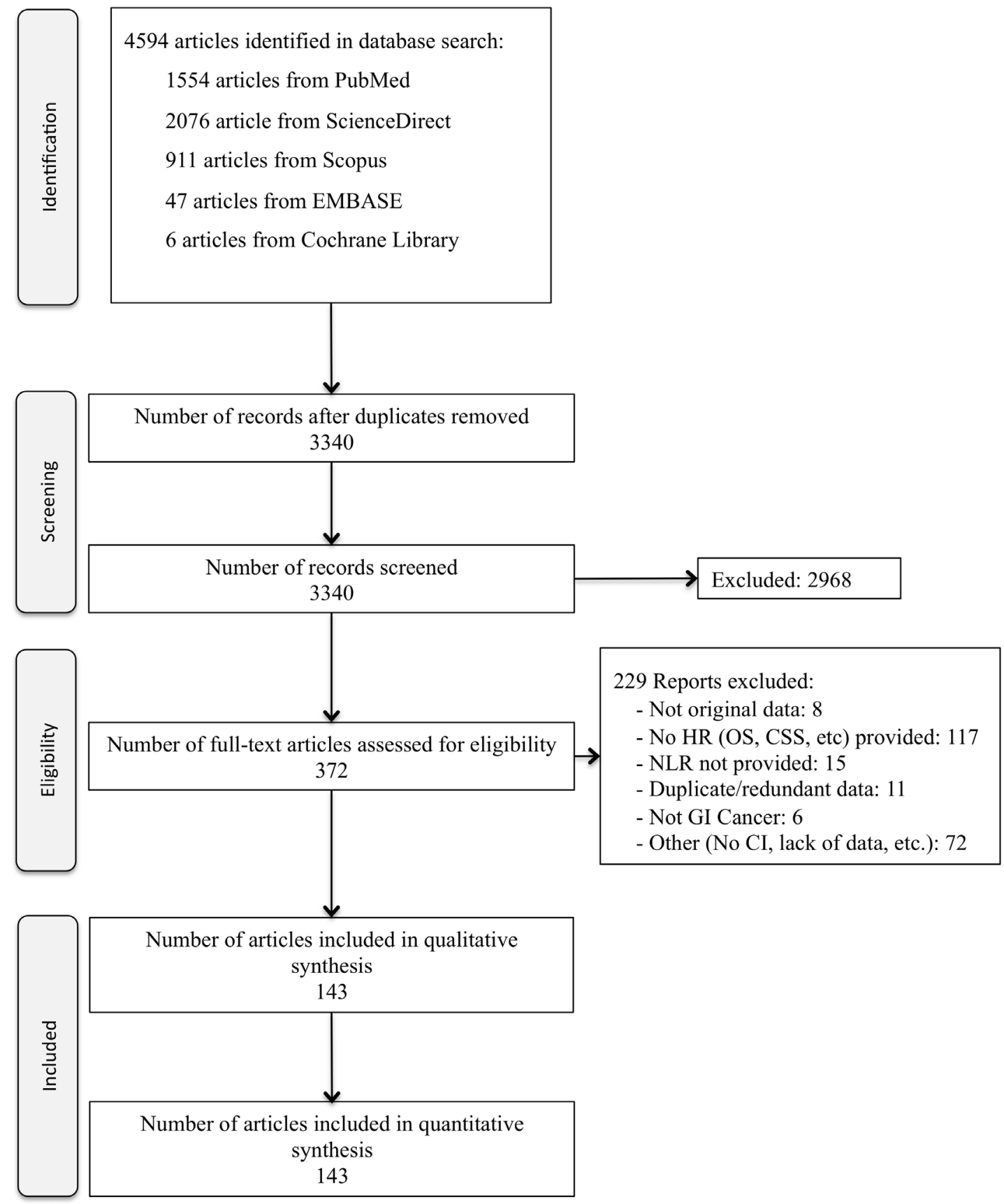

Figure 1: Flowchart of study selection. Flow diagram of study selection process for the neutrophil-lymphocyte ratio meta-analysis of GI cancers. HR = Hazard Ratio; OS = Overall survival; CSS = Cancer specific survival; NLR = Neutrophil-to-Lymphocyte ratio; GI = Gastrointestinal; CI = Confidence Interval. 
Table 1: Characteristics of included studies

\begin{tabular}{|c|c|c|c|c|c|c|}
\hline & \multirow{2}{*}{ Characteristics } & \multicolumn{2}{|c|}{ Studies } & \multicolumn{2}{|c|}{ Patients } & \multirow{2}{*}{ References } \\
\hline & & $N=144$ & $(\%)$ & $\mathrm{N}=\mathbf{4 5 , 9 0 5}$ & $(\%)$ & \\
\hline \multicolumn{7}{|c|}{ Year of Publication } \\
\hline & \begin{tabular}{l|l}
2008 \\
\end{tabular} & 1 & $(1)$ & 440 & $(1)$ & {$[41]$} \\
\hline & 2009 & 3 & $(2)$ & 614 & $(1)$ & {$[42-44]$} \\
\hline & 2010 & 5 & (3) & 1,538 & (3) & {$[45-49]$} \\
\hline & 2011 & 8 & (6) & 2,231 & $(5)$ & {$[50-57]$} \\
\hline & 2012 & 12 & $(8)$ & 4,518 & $(10)$ & {$[4,58-67]$} \\
\hline & 2013 & 14 & $(10)$ & 3,992 & $(9)$ & {$[68-81]$} \\
\hline & 2014 & 32 & $(22)$ & 8,260 & $(18)$ & [82-113] \\
\hline & 2015 & 48 & $(34)$ & 17,501 & $(38)$ & {$[5,114-160]$} \\
\hline & 2016 & 21 & $(15)$ & 6,474 & (14) & {$[161-181]$} \\
\hline \multicolumn{7}{|c|}{ Study Type } \\
\hline \multicolumn{7}{|c|}{ Case control } \\
\hline & \begin{tabular}{l|l} 
& Retrospective \\
\end{tabular} & 1 & $(1)$ & 93 & $(<1)$ & {$[62]$} \\
\hline \multicolumn{7}{|c|}{ Cohort } \\
\hline & \begin{tabular}{l|l} 
& Retrospective \\
\end{tabular} & 141 & (99) & 44,614 & $(98)$ & {$[4,41-61,63-181]$} \\
\hline \multicolumn{7}{|c|}{ Randomized control trial } \\
\hline & Prospective & 1 & (1) & 861 & $(2)$ & {$[5]$} \\
\hline \multicolumn{7}{|c|}{ Hazard Ratios } \\
\hline \multicolumn{7}{|c|}{ Overall survival } \\
\hline & Multivariate & 110 & (77) & 36,884 & $(80)$ & $\begin{array}{l}{[4,5,41-43,47-61,63-67,69,70,72,73,77,81,84,88,91-104,} \\
106,107,110-113,115-119,123-131,134,137-143,146-148, \\
151-160,164,166,168-171,173-179,181]\end{array}$ \\
\hline & Univariate & 74 & $(51)$ & 23,069 & $(50)$ & $\begin{array}{l}{[41-45,54,55,58,59,61,64-66,68,69,74,77,81,82,87,91,} \\
93,94,97-101,105,108,110,112-118,121,123-126,128-130, \\
132,134,136,137,139,140,142,144,146-148,150,151,155, \\
156,158,161,166,169,171,173-179,181]\end{array}$ \\
\hline \multicolumn{7}{|c|}{ Disease-free survival } \\
\hline & Multivariate & 44 & $(31)$ & 14201 & $(31)$ & $\begin{array}{l}{[4,42,46,52,55,57,58,62,66,67,70,75,76,89,90,92,96,} \\
97,99,100,106,109,110,112,116,117,119,120,122,125, \\
139,145,149,151,156,158,165,170,171,175,176,178,179, \\
181]\end{array}$ \\
\hline & Univariate & 35 & $(24)$ & 7745 & $(17)$ & $\begin{array}{l}{[42,44,46,55,58,66,74,75,78,83,89,90,97,100,110,112,} \\
116,117,122,125,135,137,139,144,145,151,155,156,158, \\
166,171,175,178,179,181]\end{array}$ \\
\hline \multicolumn{7}{|c|}{ Progression-free survival } \\
\hline & \begin{tabular}{l|l} 
& Multivariate \\
\end{tabular} & 7 & $(5)$ & 1,203 & (3) & {$[50,61,84,102,111,118,126]$} \\
\hline & \begin{tabular}{l|l} 
& Univariate \\
\end{tabular} & 6 & $(4)$ & 615 & $(1)$ & {$[60,61,118,126,129,147]$} \\
\hline \multicolumn{7}{|c|}{ Cancer-specific survival } \\
\hline & Multivariate & 15 & $(10)$ & 4,586 & $(10)$ & $\begin{array}{l}{[71,79,80,89,90,103,110,119,120,133,138,145,149,173 \text {, }} \\
180]\end{array}$ \\
\hline & Univariate & 13 & $(9)$ & 3,400 & (7) & {$[71,79,80,85,86,89,90,110,133,145,167,172,173]$} \\
\hline \multicolumn{7}{|c|}{ Disease Site } \\
\hline & Cholangiocarcinoma & 4 & (3) & 1,272 & (3) & {$[94,105,174,175]$} \\
\hline & Colorectal carcinoma & 47 & $(32)$ & 14,891 & $(32)$ & $\begin{array}{l}{[4,41,43,44,46,47,50,52,58,61,63,67,68,71,75,79,85,} \\
86,89,90,97-100,103,110,115,117,118,122,124-126,135, \\
137,138,140,145,147-150,155,169,172,179]\end{array}$ \\
\hline & Esophageal carcinoma & 14 & $(10)$ & 4,101 & $(9)$ & $\begin{array}{l}{[54,55,69,111,112,120,129,133,146,167,171,173,180 \text {, }} \\
181]\end{array}$ \\
\hline & Gastric cancer & 23 & $(16)$ & 11,196 & $(24)$ & $\begin{array}{l}{[48,53,60,62,66,72,73,84,87,88,95,104,119,127,130 \text {, }} \\
131,142,159,164]\end{array}$ \\
\hline & $\begin{array}{l}\text { Gastrointestinal stromal } \\
\text { tumor }\end{array}$ & 4 & $(3)$ & 630 & $(1)$ & {$[78,83,144,165]$} \\
\hline & $\begin{array}{l}\text { Hepatocellular } \\
\text { carcinoma }\end{array}$ & 34 & $(24)$ & 9,170 & $(20)$ & $\begin{array}{l}{[42,51,56,59,64,70,74,76,77,82,91,92,96,102,106,107,} \\
109,113,116,121,123,132,136,139,152,154,156-158,160, \\
168,170,176]\end{array}$ \\
\hline & Pancreatic cancer & 18 & $(13)$ & 4,642 & $(10)$ & $\begin{array}{l}{[5,45,65,80,81,93,108,114,128,134,141,151,161-163,} \\
166,177,178]\end{array}$ \\
\hline \multicolumn{7}{|c|}{ Disease Stage } \\
\hline
\end{tabular}




\begin{tabular}{|c|c|c|c|c|c|c|}
\hline & Nonmetastatic & 52 & (36) & 19,373 & (41) & $\begin{array}{l}{[4,42,46,58,59,62,68-70,74,76,78,83,86,88,90,96,100,} \\
106,107,109,111,114,117,120-122,129-133,135,137,140, \\
146,149,158,159,162,165,166,168,170,171,176,178-181]\end{array}$ \\
\hline & Metastatic & 23 & $(16)$ & 5,343 & (12) & $\begin{array}{l}{[5,41,44,50,60,61,67,82,84,95,97,101,104,115,118,124-} \\
126,138,147,150,172,177]\end{array}$ \\
\hline & Mixed & 69 & $(48)$ & 21,189 & (46) & $\begin{array}{l}{[43,45,47-49,51,53-57,63-66,71-73,75,77,79-81,85,87,89,} \\
91-94,98,99,102,103,105,108,110,112,113,116,119,123, \\
127,128,134,136,139,141-145,148,151-157,160,161,163, \\
164,167,169,173-175]\end{array}$ \\
\hline \multicolumn{7}{|c|}{ Treatment Method } \\
\hline & Resection & 52 & (36) & 19,798 & (43) & $\begin{array}{l}{[42,46,48,52,62,69,70,72,74-76,78,79,83,85,86,92,96,} \\
104-106,109,116,117,119,120,122,127,130-133,135,139, \\
140,142,146,149,153,157,158,163,165-171,175,176,178]\end{array}$ \\
\hline & Chemotherapy & 19 & $(13)$ & 4,071 & (9) & $\begin{array}{l}{[5,45,50,51,60,61,81,84,91,102,107,108,118,121,126,} \\
134,141,147,174]\end{array}$ \\
\hline & Radiation & 2 & $(1)$ & 366 & $(1)$ & {$[59,161]$} \\
\hline & Mixed & 71 & $(49)$ & 21,670 & (47) & $\begin{array}{l}{[4,41,43,44,47,49,53-58,63,64,66-68,71,73,77,80,82,} \\
87-90,93-95,97-101,103,110-115,123-125,128,129,136-138, \\
143-145,148,150-152,154-156,159,160,162,164,172,173, \\
177,179-181]\end{array}$ \\
\hline \multicolumn{7}{|c|}{ NLR Cutoff } \\
\hline & $<3.0$ & 55 & $(38)$ & 19,656 & (43) & $\begin{array}{l}{[47,53,57,59,62,70,72,77-79,83,88,90-92,97,98,100-102,} \\
105,107,111,114,116,117,119,120,123,124,126,128-133, \\
140-142,144-146,148,153,156,160,162,164,169,170,173, \\
176,180,181]\end{array}$ \\
\hline & 3.0 to 3.99 & 35 & $(24)$ & 12,197 & (27) & $\begin{array}{l}{[4,5,51,57,60,69,73,81,84,85,87,89,94,95,104,109,110,} \\
121,122,134-136,138,143,147,149,155,159,163,166-168, \\
175,177]\end{array}$ \\
\hline & 4.0 to 4.99 & 14 & $(10)$ & 3,501 & $(8)$ & {$[46,48,54,61,68,76,82,103,106,125,137,154,157,158]$} \\
\hline & $\geq 5.0$ & 40 & $(28)$ & 10,214 & (22) & $\begin{array}{l}{[41,43-45,49,50,52,55,58,63-67,71,74,75,80,86,93,96,} \\
99,108,112,113,115,118,127,139,150-152,165,171,172, \\
174,178,179]\end{array}$ \\
\hline \multicolumn{7}{|c|}{ Study Origin } \\
\hline \multicolumn{7}{|c|}{ Asia/Oceania } \\
\hline & \begin{tabular}{l|l} 
& Australia \\
\end{tabular} & 4 & $(3)$ & 1,552 & $(3)$ & {$[5,50,93,179]$} \\
\hline & China & 48 & $(33)$ & 16,051 & (37) & $\begin{array}{l}{[45-47,51,56,57,65-67,69,70,88,91,92,100,104-107,110,} \\
112-114,116,119-121,123,129,132-134,141-143,146,153, \\
156-160,168,170,175,176,180,181]\end{array}$ \\
\hline & Japan & 30 & $(21)$ & 7,704 & (17) & $\begin{array}{l}{[48,49,54,61,76,79,82,87,90,95,101,102,108,109,128,} \\
135,137,139,147,148,154,155,162,163,166,167,169,172, \\
173,178]\end{array}$ \\
\hline & Korea & 21 & $(15)$ & 6,880 & (15) & $\begin{array}{l}{[53,60,62,63,72,73,77,84,85,89,96,99,111,130,131,145,} \\
149,150,171,174,177]\end{array}$ \\
\hline & Singapore & 1 & $(1)$ & 300 & (1) & {$[165]$} \\
\hline & \begin{tabular}{l|l} 
Taiwan \\
\end{tabular} & 5 & $(4)$ & 5,311 & $(12)$ & {$[4,52,59,127]$} \\
\hline \multicolumn{7}{|c|}{ Europe/ Mediterranean } \\
\hline & Austria & 3 & $(2)$ & 1,552 & $(2)$ & {$[68,80,124]$} \\
\hline & Ireland & 1 & $(1)$ & 85 & $(0)$ & [81] \\
\hline & Italy & 4 & $(3)$ & 699 & $(2)$ & {$[118,122,126,164]$} \\
\hline & Turkey & 2 & $(1)$ & 348 & $(1)$ & {$[83,98]$} \\
\hline & \begin{tabular}{l|l} 
& United Kingdom \\
\end{tabular} & 13 & $(9)$ & 2,689 & (6) & {$[41,42,44,58,64,71,75,86,97,103,125,138,140]$} \\
\hline \multicolumn{7}{|c|}{ Northern America } \\
\hline & Canada & 3 & $(2)$ & 1,506 & (3) & {$[94,117,144]$} \\
\hline & United States & 9 & $(6)$ & 1,968 & (4) & {$[43,55,74,78,115,136,151,152,161]$} \\
\hline
\end{tabular}

and 19 studies performed analyses on OS, DFS, PFS, and CSS, respectively. Gastrointestinal disease site included cholangiocarcinoma, colorectal carcinoma, esophageal carcinoma, gastric cancer, gastrointestinal stromal tumor, hepatocellular carcinoma, and pancreatic cancer. Of the 144 cancer site studies, 52 included non-metastatic cancer, 23 included metastatic cancers, and 69 included a mix of both disease stages. Participants in 71 studies received more than one treatment modality (chemotherapy, surgery, radiation), participants in 52 studies underwent only surgery as therapy, 19 studies reported only chemotherapy, and participants in two studies were treated only with radiation therapy. Studies were conducted in multiple countries including Australia $(N=4 ; 2.8 \%)$, Austria $(N=3 ; 2.1 \%)$, Canada $(N=3 ; 2.1 \%)$, China $(N=48$; $33.3 \%)$, Ireland $(N=1 ; 0.7 \%)$, Italy $(N=4 ; 2.8 \%)$, Japan $(N=30 ; 20.8 \%)$, Singapore $(N=1 ; 0.7 \%)$, Korea $(N=$ $21 ; 14.6 \%)$, Taiwan $(N=5 ; 3.5 \%)$, Turkey $(N=2 ; 1.4 \%)$; 
Table 2: Sensitivity analysis

\begin{tabular}{|c|c|c|c|c|}
\hline Studies & HR & UL of $95 \%$ CI & LL of $95 \%$ CI & $\begin{array}{l}P \text { of heterogeneity chi- } \\
\text { squared }\end{array}$ \\
\hline \multicolumn{5}{|l|}{ Overall survival } \\
\hline Model type & & & & 0.001 \\
\hline Multivariate & 1.63 & 1.53 & 1.73 & \\
\hline Univariate & 1.92 & 1.78 & 2.08 & \\
\hline C-index & & & & 0.002 \\
\hline Yes & 1.45 & 1.35 & 1.56 & \\
\hline No & 1.79 & 1.60 & 2.00 & \\
\hline NLR cutoff & & & & 0.026 \\
\hline$\leq 3$ & 1.54 & 1.43 & 1.64 & \\
\hline$>3$ & 1.83 & 1.60 & 2.10 & \\
\hline Stage & & & & 0.565 \\
\hline Metastatic & 1.75 & 1.36 & 2.24 & \\
\hline Mixed & 1.67 & 1.54 & 1.81 & \\
\hline Nonmetastatic & 1.56 & 1.39 & 1.76 & \\
\hline \multicolumn{5}{|c|}{ Disease free survival } \\
\hline Model type & & & & 0.142 \\
\hline Multivariate & 1.71 & 1.52 & 1.91 & \\
\hline Univariate & 1.99 & 1.69 & 2.36 & \\
\hline C-index & & & & 0.005 \\
\hline Yes & 1.48 & 1.31 & 1.67 & \\
\hline No & 2.10 & 1.70 & 2.60 & \\
\hline NLR cutoff & & & & 0.012 \\
\hline$\leq 3$ & 1.48 & 1.34 & 1.63 & \\
\hline$>3$ & 2.12 & 1.63 & 2.76 & \\
\hline Stage & & & & 0.799 \\
\hline Metastatic & 1.51 & 0.90 & 2.53 & \\
\hline Mixed & 1.78 & 1.42 & 2.22 & \\
\hline Nonmetastatic & 1.66 & 1.45 & 1.91 & \\
\hline \multicolumn{5}{|c|}{ Progression free survival } \\
\hline Model type & & & & 0.728 \\
\hline Multivariate & 1.64 & 1.36 & 1.97 & \\
\hline Univariate & 1.45 & 0.74 & 2.82 & \\
\hline C-index & & & & 0.785 \\
\hline Yes & 1.76 & 1.28 & 2.41 & \\
\hline No & 1.66 & 1.26 & 2.19 & \\
\hline NLR cutoff & & & & 0.140 \\
\hline$\leq 3$ & 1.51 & 1.28 & 1.78 & \\
\hline$>3$ & 2.27 & 1.36 & 3.81 & \\
\hline Stage & & & & 0.386 \\
\hline Metastatic & 1.78 & 1.36 & 2.34 & \\
\hline Mixed & 1.36 & 1.01 & 1.84 & \\
\hline Nonmetastatic & 1.80 & 1.05 & 3.08 & \\
\hline \multicolumn{5}{|c|}{ Cancer specific survival } \\
\hline Model type & & & & 0.117 \\
\hline Multivariate & 1.83 & 1.50 & 2.23 & \\
\hline Univariate & 2.27 & 1.89 & 2.72 & \\
\hline
\end{tabular}




\begin{tabular}{|l|l|l|l|l|}
\hline C-index & & & & 0.105 \\
\hline Yes & 1.61 & 1.24 & 2.10 & \\
\hline No & 2.12 & 1.73 & 2.60 & \\
\hline NLR cutoff & & & & 0.173 \\
\hline$\leq 3$ & 1.59 & 1.35 & 1.88 & \\
\hline$>3$ & 2.20 & 1.42 & 3.40 & \\
\hline Stage & & & & 0.049 \\
\hline Metastatic & 1.93 & 1.40 & 2.66 & \\
\hline Mixed & 2.18 & 1.68 & 2.84 & \\
\hline Nonmetastatic & 1.37 & 1.04 & 1.80 & \\
\hline
\end{tabular}

Abbreviations: $\mathrm{HR}=$ Hazard ratio, NLR $=$ Neutrophil-to-lymphocyte ratio, $\mathrm{C}$-index $=$ Receiver operating characteristic curves for selection of cutoff,

Table 3: Risk of bias percent summary

\begin{tabular}{|l|l|l|l|l|l|l|l|}
\hline \multicolumn{7}{|c|}{ Risk of Bias Summary Analysis } & \\
\hline $\begin{array}{c}\text { Risk of Bias } \\
\text { Severity }\end{array}$ & $\begin{array}{c}\text { Bias due to } \\
\text { confounding }\end{array}$ & $\begin{array}{c}\text { Bias in } \\
\text { selection of } \\
\text { participants } \\
\text { into study }\end{array}$ & $\begin{array}{c}\text { Bias in } \\
\text { measurement } \\
\text { of } \\
\text { intentions } \\
\text { Bias due to } \\
\text { departures } \\
\text { from intended } \\
\text { interventions }\end{array}$ & $\begin{array}{c}\text { Bias due to } \\
\text { missing data }\end{array}$ & $\begin{array}{c}\text { Bias in } \\
\text { measurement } \\
\text { of outcomes }\end{array}$ & $\begin{array}{c}\text { Bias in selection } \\
\text { of reported } \\
\text { result }\end{array}$ \\
\hline Low & $\mathrm{N}=8 ; 6 \%$ & $\mathrm{~N}=136 ; 95 \%$ & $\mathrm{~N}=136 ; 95 \%$ & $\mathrm{~N}=139 ; 97 \%$ & $\mathrm{~N}=135 ; 94 \%$ & $\mathrm{~N}=143 ; 100 \%$ & $\mathrm{~N}=127 ; 89 \%$ \\
\hline Moderate & $\mathrm{N}=112 ; 78 \%$ & $\mathrm{~N}=7 ; 5 \%$ & $\mathrm{~N}=7 ; 5 \%$ & $\mathrm{~N}=3 ; 2 \%$ & $\mathrm{~N}=8 ; 6 \%$ & $\mathrm{~N}=0 ; 0 \%$ & $\mathrm{~N}=16 ; 11 \%$ \\
\hline Serious & $\mathrm{N}=21 ; 15 \%$ & $\mathrm{~N}=0 ; 0 \%$ & $\mathrm{~N}=0 ; 0 \%$ & $\mathrm{~N}=1 ; 1 \%$ & $\mathrm{~N}=0 ; 0 \%$ & $\mathrm{~N}=0 ; 0 \%$ & $\mathrm{~N}=0 ; 0 \%$ \\
\hline Critical & $\mathrm{N}=2 ; 1 \%$ & $\mathrm{~N}=0 ; 0 \%$ & $\mathrm{~N}=0 ; 0 \%$ & $\mathrm{~N}=0 ; 0 \%$ & $\mathrm{~N}=0 ; 0 \%$ & $\mathrm{~N}=0 ; 0 \%$ & $\mathrm{~N}=0 ; 0 \%$ \\
\hline
\end{tabular}

United Kingdom $(N=13 ; 9 \%)$, and the United States $(N$ $=9 ; 6.3 \%)$. The median cutoff for the NLR among all included studies was $3.0( \pm \mathrm{IQR}=2.495-5.0)$. There were 229 studies excluded, most commonly due to the absence of primary outcome measurements (OS, DFS, PFS, and CSS) or the HR for these primary outcomes. Full text papers could not be located for 2 studies. In cases where there were redundant study populations between multiple publications, we only used the most recent publication and excluded prior studies (Table 1).

\section{Overall survival}

110 studies including 36,884 patients reported a HR for OS based on a multivariate model. 6 studies reported a HR for OS, but failed to use a multivariate model and therefore were not included in our main analysis. For an analysis of hazard ratios for OS using univariate models, see Table 2. The mean, median, and mode cutoff for NLR reporting OS from multivariate model was 3.4, 3.0, 5.0 $( \pm$ IQR $2.5,5.0)$, respectively with 39 studies using 5.0 compared to 25 studies using 3.0. A forest plot depicting OS for included studies is shown in Figure 2. Overall, NLR greater than the cutoff value was associated with a hazard ratio for OS of $1.63(95 \%$ CI 1.53 to $1.73 ; P<$ $0.001)$.
The prognostic effect of NLR on OS among subgroups based on disease site is shown in Figure $2 \mathrm{~A}$. The disease site with the greatest HR for OS was colorectal cancer $(\mathrm{HR}=2.04 ; 95 \% \mathrm{CI} 1.79$ to 2.33 ), followed by pancreatic cancer $(\mathrm{HR}=1.90 ; 95 \% \mathrm{CI} 1.43$ to 2.52$)$, esophageal carcinoma $(\mathrm{HR}=1.61 ; 95 \% \mathrm{CI} 1.32$ to 1.95$)$, cholangiocarcinoma $(\mathrm{HR}=1.53 ; 95 \%$ CI 1.14 to 2.05$)$, gastric cancer $(\mathrm{HR}=1.47 ; 95 \% \mathrm{CI} 1.25$ to 1.72$)$ and hepatocellular carcinoma $(\mathrm{HR}=1.40 ; 95 \%$ CI 1.30 to 1.52 ).

The prognostic effect of NLR on OS among subgroups based on geographic location is shown in Figure 2B. The largest portion of patients in the OS analysis was in the Asia/Oceania region (81.07\%), but they had the lowest HR at 1.53 (95\% CI 1.43 to 1.63). By comparison, the HR for Northern America was 1.64 (95\% CI 1.38 to 1.95$)$ and the HR for Europe/Mediterranean was 2.32 (95\% CI 1.93 to 2.77$)$.

The prognostic effect of NLR on OS among subgroups based on disease stage is shown in Figure 2C. The median NLR cutoff value for metastatic disease was 3.55 ( \pm IQR 3 to 5), whereas the median NLR cutoff value for nonmetastatic disease was 2.97 ( $\pm \mathrm{IQR} 2$ to 4$)$. This difference between the NLR cutoff values in metastatic versus nonmetastatic disease was statistically significant $(P=0.0134)$. The HR for a high NLR on OS in metastatic disease was 1.75 (95\% CI 1.36 to 2.24$)$. The HR for 
nonmetastatic disease was 1.56 (95\% CI 1.36 to 1.76$)$. The HR for mixed disease stages was 1.67 (95\% CI 1.54 to 1.81). There was no statistical difference in OS between the nonmetastatic and metastatic cancer groups at their NLR cutoff values $(0.64$; d.f. $=1 ; P=0.423)$. Sensitivity analyses of the included studies are reported in Table 2. In analyzing OS, we found statistically significant differences in HR when comparing multivariate and univariate analyses $(P=0.001)$, presence of $\mathrm{C}$-index to select NLR cutoff $(P=0.002)$, and NLR $<3$ compared to $>3(P=$ $0.026)$. However, there was no difference when comparing disease stages (metastatic, mixed, non-metastatic $(P=$ $0.565)$ ). The meta-regression scatter plot showed minor but statistically significant association between NLR cutoff and the hazard ratio for $\operatorname{OS}(\beta=0.224 ; P=0.019)$ (Supplementary Figure 1).

\section{Disease-free (recurrence-free) survival}

44 studies including 14,201 patients reported hazard ratios for DFS or RFS analyzed in a multivariate model. The median cutoff for a high NLR was $3( \pm$ IQR 2.4 to
5.0). For DFS, NLR greater than the cutoff value was associated with a HR of $1.70(95 \%$ CI 1.52 to $1.91, P<$ 0.001 ; I-squared $=76.5 \%$ ). There were not statistically significant differences among the hazard ratios of different subgroups based on disease site (Heterogeneity chisquared $=3.74($ d.f. $=6) P=0.711)($ Figure $3 \mathrm{~A})$. For an analysis of hazard ratios for DFS using univariate models, see Table 2.

\section{Progression-free survival}

7 studies including 1,213 patients reported hazard ratios for PFS analyzed in a multivariate model. The median cutoff for a high NLR was 3 ( \pm IQR 2 - 5). For PFS, NLR greater than the cutoff value was associated with a HR of $1.64(95 \%$ CI 1.36 to $1.97, P<0.001$; I-squared $=21.0 \%$ ). There were not statistically significant differences among the hazard ratios of different subgroups based on disease site (Heterogeneity chi-squared $=3.37$ $($ d.f. $=3) P=0.338$ ) (Figure $3 \mathrm{~B})$. For an analysis of hazard ratios for PFS using univariate models, see Table 2.

\section{A. GI cancer site}

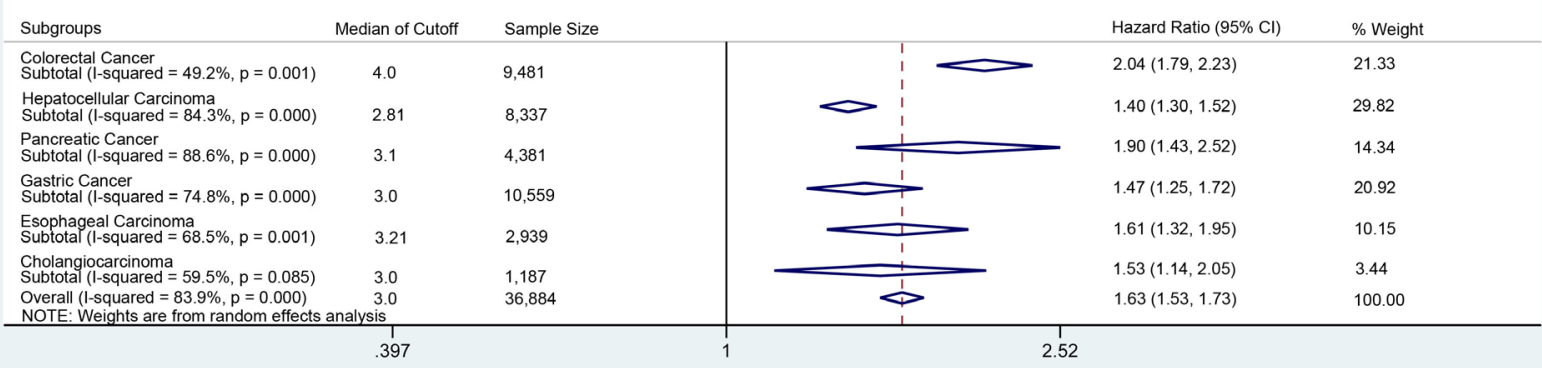

\section{B. Geographic}

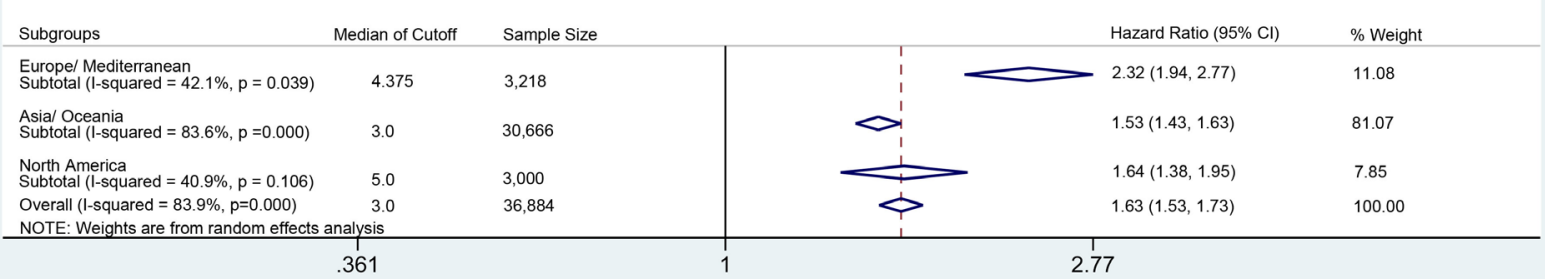

\section{Cancer stage}

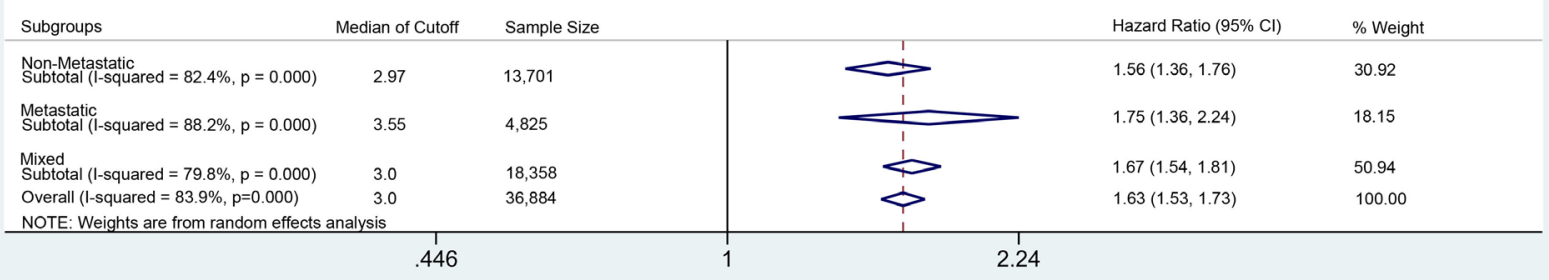

Figure 2: Overall survival analysis. Overall survival analysis of NLR cut off, geographic location, and disease stage. A. Overall survival in patients with GI cancers and per individual GI cancer types. B. Overall survival analysis within geographic regions. C. Overall survival within each disease stage. 


\section{Cancer-specific survival}

15 studies including 4,586 patients reported hazard ratios for CSS analyzed in a multivariate model. The median cutoff for a high NLR was 3 ( \pm IQR 2.36 - 4.75). For CSS, NLR greater than the cutoff value was associated with a $\mathrm{HR}$ of $1.83(95 \% \mathrm{CI}=1.50$ to $2.23, P<0.001$; I-squared $=56.9 \%)$. There was a small, but statistically significant difference in the hazard ratios for CSS between the colorectal cancer and esophageal carcinoma subgroups (Heterogeneity chi-squared $=7.82 ;($ d.f. $=1) ; P=0.005)$ (Figure $3 \mathrm{C}$ ). For an analysis of hazard ratios for CSS using univariate models, see Table 2.

The heterogeneity observed in these analyses was largely due to observational studies and variation between comparable characteristic, such as the use of C-index to determine the NLR cut-off value and whether the patient had metastatic versus non-metastatic lesions (Table 2). We found that the HR for studies without $\mathrm{C}$-index justification was 1.79 (95\% 1.60 to 2.00), and the HR for studies using $\mathrm{C}$-index as justification is 1.45 (95\% 1.35 to 1.56$)$. The p-value for chi-squared test is 0.002 for these two groups. This indicated that studies which failed to report how they chose cutoff are more likely to report higher HR, compared to studies reported how they chose the cutoff of NLR.

\section{Risk of bias summary}

Confounding was the most severe risk of bias within our included studies (Table 3 and Supplementary Figure 2 ). The retrospective nature of most studies accounted for the high likelihood for confounding variables. Many studies performed analyses to adjust for confounders. Bias in selection of participants and in measurement of interventions was low risk in the majority of studies. In terms of bias due to departures from intended interventions, three studies displayed moderate risk and one had serious risk. Bias due to missing data was primarily low risk due to the lack of missing observations and incomplete data reporting. Bias in selection of the reported outcomes was mostly attributed to lack of measurement reporting and lack of utilizing numerous analysis methods. A funnel plot revealed potential publication bias as seen with asymmetric distribution (Supplementary Figure 3). The Egger's test indicated possible publication bias with the regression line not originating in the Y-axis zero (Bias $=4.165$ (95\% CI 3.546 to 4.784$) P<0.001$ ) as well as a $P<0.05$ indicating small study effect (Supplementary Figure 4 ).

\section{DISCUSSION}

An accurate, time efficient, and inexpensive prognostic indicator is needed to reduce cost and assist with clinical decision making for cancer management. In this systematic review and meta-analysis, we identified over a decade and a half of data from 45,905 GI cancer patients that underwent neutrophil-to-lymphocyte ratio testing to determine OS as well as DFS, PFS, or CSS. 143 studies were retrospective, with one correlation study of NLR with a phase III RCT [5]. We report overall moderate risk of bias in our studies due the effects of retrospective analyses with confounding, small sample-size, and variation in some comparable measurements. Colorectal, gastric, and hepatocelluar were the most common cancer sites. Asian populations were the most frequently studied, representing $76 \%$ of the total number of patients. The pooled HR for OS was 1.63 (95\% CI 1.53 to 1.73 ), indicating that patients with NLR higher than cutoff were $63 \%$ more likely to die than patients with NLR lower than the cutoff. OS greater than NLR cutoff was independent of geographic location, GI cancer type, or stage of cancer (Figure 2). The overall median NLR cutoff for OS was 3.0, which was lower than other studies comparing solid tumors [6]. Our analysis shows that a NLR greater than the cutoff value predict worse OS.

Overall HR of DFS (1.70), PFS (1.64), and CSS (1.83), also suggest that elevated NLR indicate worse prognosis. However, since PFS analyzes disease progression, a low NLR cutoff may not result in a significant difference; consequently, a higher cutoff level may be more appropriate for metastatic disease.

Across all geographic locations we found that patients with elevated NLR were more likely to have worse OS. This further supports the prognostic value of NLR in GI cancers, independent of genetic variation at the population level. Individual-level analyses are needed to further validate this hypothesis. Interestingly, studies of European/Mediterranean patients had a significantly larger HR than studies from Asia/Oceania and North America. This could mean that people of Europe/Mediterranean are more sensitive to high NLR for worse OS, or that Europe/Mediterranean studies are more likely to report a higher HR. Possible confounding factors include poor study design, difference in patterns of care in geographic locations or small sample sizes. Despite these differences, our geographic analysis supports NLR above cutoff as a predictive index for overall survival.

The heterogeneity observed in these analyses was largely due to observational studies and variation between comparable characteristic, such as the use of C-index to determine the NLR cut-off value and whether the patient had metastatic versus non-metastatic lesions (Table 2). We found that the HR for studies without $\mathrm{C}$-index justification was 1.79 (95\% 1.60 to 2.00$)$, and the HR for studies using $\mathrm{C}$-index as justification is 1.45 (95\% 1.35 to 1.56$)$. The p-value for the chi-squared test was 0.002 for these two groups. This suggests that studies without $\mathrm{C}$-index justification were more likely to report higher HR. 


\section{Prognostic value of the NLR}

The association between chronic inflammation and carcinogenesis has long been recognized, with examples such as gastric reflux and esophageal adenocarcinoma, H. pylori infection and gastric cancers, and chronic colonic ulcers and adenocarcinoma of the colon. More recently, the role of inflammation in tumor progression has been explored, with particular focus on the tumor microenvironment. Interactions between tumor and immune cells result in manipulation and misregulation of the immune response. Elevated NLR suggests a systemic inflammatory state and can be indicative of neutrophilia, lymphopenia, or a combination of both. It has been linked to disease states including but not limited to endometriosis [7], acute coronary syndrome [8], Alzheimer's disease [9], and a variety of cancers. Subsequent investigations have explored its use as a prognostic factor.

Neutrophilia can occur in cancer patients due to increased myeloid cell production, potentially resulting from ectopic colony-stimulating factor $[10,11]$. Not only can circulating neutrophil levels rise, but neutrophils can localize to the tumor due to multiple factors, including general inflammatory signals like IL-1 and TNF-alpha [12], as well as IL-8 release triggered by hypoxic conditions of the tumor microenvironment [13]. Once present, TGF- $\beta$ [14] produced by altered stromal cells [15] can activate neutrophils. Although many of the details are unclear, neutrophils are thought to primarily propagate a pro-tumor environment by secreting molecules such as VEGF, MMP-9 [16], and reactive oxygen species [17]. The respective effects of these molecules include promoting angiogenesis and tumor growth, degrading the ECM and providing favorable conditions for metastasis, and potentiating genome instability and tumor evolution. A recent study also demonstrated the expression of the T-cell-negative-regulatory molecule PD-L1 on tumor infiltrating neutrophils that could functionally inhibit the activation of T cells [18].

Lymphopenia in the context of cancer also suggests more aggressive disease progression. Examinations of the tumor microenvironment have shown a correlation between tumor-infiltrating lymphocytes (TILs) and

\section{A. Disease free survival}

\begin{tabular}{|c|c|c|c|c|c|}
\hline Subgroups & Median of Cutoff & Sample Size & & Hazard Ratio $(95 \% \mathrm{Cl})$ & $\%$ Weight \\
\hline $\begin{array}{l}\text { Colorectal Cancer } \\
\text { Subtotal (I-squared }=63.0 \%, p=0.000)\end{array}$ & 3.0 & 7,131 & $\stackrel{1}{\longrightarrow}$ & $1.75(1.44,2.12)$ & 36.43 \\
\hline $\begin{array}{l}\text { Hepatocellular Carcinoma } \\
\text { Subtotal (l-squared }=80.9 \%, p=0.000 \text { ) }\end{array}$ & 3.0 & 3,802 & $\underset{1}{4}$ & $1.71(1.40,2.09)$ & 34.22 \\
\hline $\begin{array}{l}\text { Pancreatic Cancer } \\
\text { Subtotal (l-squared }=86.2 \%, p=0.000)\end{array}$ & 5.0 & 480 & 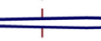 & $2.49(0.51,9.34)$ & 3.70 \\
\hline $\begin{array}{l}\text { Gastrointestinal Stromal Tumor } \\
\text { Subtotal (Only one sutdy) }\end{array}$ & 3.0 & 300 & 1 & $2.16(1.19,3.94)$ & 1.91 \\
\hline $\begin{array}{l}\text { Gastric Cancer } \\
\text { Subtotal }(l-\text {-squared }=0.0 \%, p=0.803 \text { ) }\end{array}$ & 2.36 & 806 & $\frac{1}{1}$ & $1.42(1.11,1.81)$ & 6.26 \\
\hline $\begin{array}{l}\text { Esophageal Carcinoma } \\
\text { Subtotal }(\mathrm{l} \text {-squared }=86.7 \%, p=0.000)\end{array}$ & 3.0 & 1,580 & 1 & $1.67(1.18,2.38)$ & 15.58 \\
\hline $\begin{array}{l}\text { Cholangiocarcinoma } \\
\text { Subtotal (Only one study) }\end{array}$ & 3.0 & 102 & $\frac{1}{1}$ & $2.26(1.24,4.11)$ & 1.91 \\
\hline $\begin{array}{l}\text { Overall (l-squared }=76.5 \%, p=0.000 \text { ) } \\
\text { NOTE: Weights are from random effects an }\end{array}$ & $\begin{array}{r}3.0 \\
\text { nalysis }\end{array}$ & 14,201 & $\underset{1}{\infty}$ & $1.70(1.52,1.91)$ & 100.00 \\
\hline & .107 & & & 9.34 & \\
\hline
\end{tabular}

\section{B. Progression free survival}

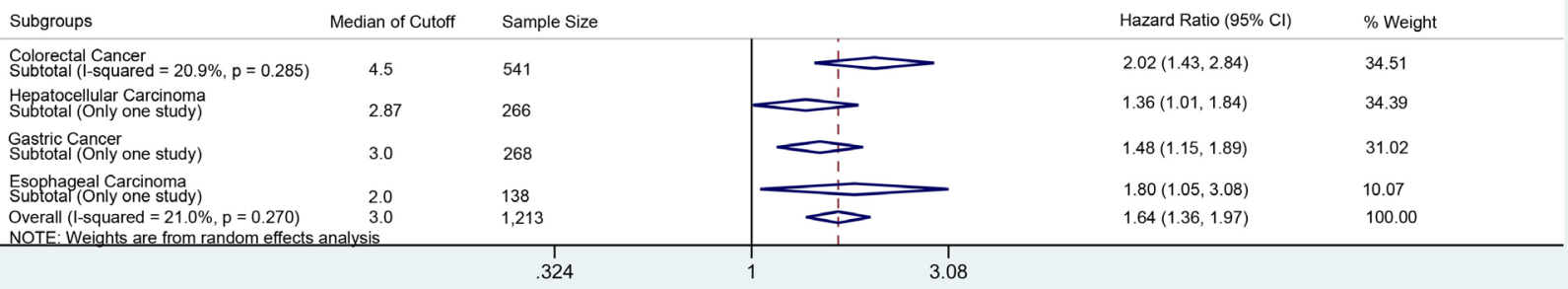

\section{Cancer specific survival}

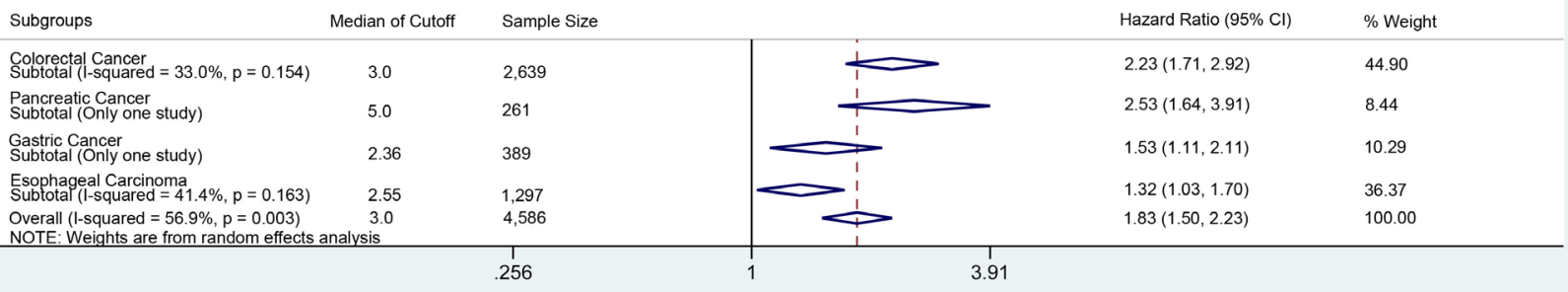

Figure 3: Disease and progression free survival with cancer-specific survival analysis. Subgroup survival analysis based on cancer site. A. Disease-free survival of five cancer types. B. Progression free survival of four cancer types. C. Cancer specific survival of four cancer types. 
prognosis in gastrointestinal $[19,20]$ and many other cancers [21], with decreased TIL populations linked to worse survival, and vice versa. The details, however, of lymphopenia are more convoluted than that of neutrophilia, in part due to the varied subsets and roles of lymphocytes. The immune system can produce tumorspecific $\mathrm{CD} 8+$ cytotoxic $\mathrm{T}$ cells (CTLs) that act to inhibit tumor progression [22], and thus lymphopenia suggests that the immune system is unable to perform anti-tumor activities. Tumors are postulated to evade the cytotoxic effects of CTLs [23] via evolving anti-apoptotic genes [24] or modulating the expression levels of cell-cell interaction proteins $[25,26]$. CD4 $+\mathrm{T}$ cells are also found in the tumor microenvironment, the majority of which are regulatory T cells (Tregs) and Th17 cells [27]. Tregs are elevated in many cancers and are considered to be generally immunosuppressive, thus limiting the host immune response to the tumor and enabling tumor progression. While there is nuance when exploring the different lymphocyte subtypes and comparing tumors of different origins, in broad terms, lymphocytes have anti-tumor activity and thus lymphopenia indicates an environment conducive to tumor progression. Whether due to neutrophilia or lymphopenia, elevated NLR physiologically suggests an inability of the immune system to suppress cancer progression. Consequently, the NLR cut-off value leverages the balance of neutrophilia and leukopenia to suggests a quantitative index for overall survival in GI cancer patients.

NLR offers a noninvasive, low-cost, early opportunity to assess patient status and prognosis. Costs of cancer are increasing rapidly; in the US alone, an estimated $\$ 124.57$ billion was spent in 2010 and that is projected to grow to $\$ 157.77$ billion by 2020 [28]. These costs are concentrated in initial and terminal stages across multiple types of cancer, including but not limited to gastrointestinal cancers [29]. The majority of these expenses are incurred via hospital costs [30] and increases are largely driven by growing use and cost of chemotherapy and radiation therapy [31]. NLR could be used, for instance, prior to intervention to allow patients and physicians to make better decisions about the course of treatment that may be more cost-effective. For example, BRAF inhibitor has been shown to induce $\mathrm{CD} 8+\mathrm{T}$ cells infiltration into tumors and may even be dependent on immune infiltration for its anticancer activity [32]. Therefore, NLR could potentially be used to select patients who may or may not benefit from BRAF inhibitor. Determining which patients will most benefit from treatment is especially important in light of increasing treatment costs [33]. NLR does not have the specificity of biomarkers derived from tumor tissue, such as analysis of gene mutations or protein expression levels, and hence has limitations on the applicability of some targeted therapies. However, many of these other biomarkers currently in use or development require obtaining tissue and are orders of magnitude more expensive than calculating NLR.
Elevated NLR is particularly attractive as a prognostic biomarker for cancer due to its affordability and accessibility. NLR is derived from complete blood count $(\mathrm{CBC})$ analysis, which is regularly measured in cancer patients, and thus does not pose an additional cost or burden to patients or the medical system. Furthermore, the technology to analyze CBC, and thus NLR, is found beyond developed economies. Efficacious and inexpensive tools need to be explored for global use to deal with the rising incidence of cancer [34]. Developing and employing NLR as a prognostic biomarker for gastrointestinal cancers has the potential to impact a large number of patients and to improve clinical decision-making. Refining our understanding of NLR via continued and prospective study, as well as finding other low-cost biomarkers, should be a future focus in order for medical systems around the globe to improve health care access.

\section{Study strengths and limitations}

We performed a detailed literature search using 5 search engines aggregating data from over 45,500 patients. We included both English and non-English publications. Furthermore, we used Cochrane and other risk of bias analysis tools to provide insight to the weaknesses and strengths of each study. The funnel plot asymmetry suggests publication bias, which has a variety of potential sources. First, extrapolating from the results of the sensitivity analysis (Table 2), NLR might have a better predictability for patients with an advanced cancer stage. We did not have an inclusion criteria for the cancer stage. Among the 112 studies which reported an adjusted HR for OS, 57 studies did not report the cancer stage of patients. Second, we did not limit the types of treatment and cancer in the pooled analysis. The NLR may have different predictability for patients receiving different treatments. Another possibility is the heterogeneity in the methodological quality of each study. Confounding effect was reported as overall moderate as a consequence of the retrospective analyses, and could contribute to funnel plot asymmetry. Limitations of this study include the predominance of observational studies and lack of RCTs. Further complication to the primary outcomes are the known correlation of NLR with other life threatening condition such as cardiovascular [35, 36], renal [37], and hepatic disease [38]. Therefore, to mitigate confounding, incorporating NLR in future RCTs is needed.

\section{CONCLUSIONS}

Our meta-analysis pooled 45,905 patients to assess the prognostic indication of NLR with GI cancers reported in 144 studies of variable risk of bias. These studies evaluated the prognostic significance of elevated NLR in different GI cancers. Our meta-analysis suggests that across all GI cancers identified in this study, a NLR 
greater than cutoff values indicates reduced OS regardless of geographic location or cancer stage. Furthermore, worse DFS, PFS, and CSS outcomes were associated with high NLR. The individual cancer types analyzed and disease stages had varying median NLR cutoff values that appear to predict survival prognosis and could be used for appropriate treatment planning. NLR should be included in correlative studies in future clinical trials to further assess and validate these findings.

\section{MATERIALS AND METHODS}

We conducted a meta-analysis of published literature using the Meta-analysis Of Observational Studies in Epidemiology (MOOSE) guidelines [39]. We considered studies that compared serum NLR to the OS, DFS, PFS or CSS of patients with GI cancers. The primary endpoints were overall survival (OS) by cancer site, geographic location, and cancer stage using multivariate analysis. We included DFS, PFS and CSS as secondary endpoints analyses based on cancer site. Univariate analyses of OS, DFS, PFS and CSS for each GI cancer type were also performed.

\section{Inclusion/exclusion criteria}

We included studies that met the following criteria: 1) randomized controlled trials (RCT), quasi-RCT, cohort, or case control; 2) patient size greater than $N=20$ patients; 3 ) analyzed humans with GI cancers that included NLR and hazard ratios with associated $95 \%$ confidence interval with OS, DFS, PFS, and CSS. We defined GI cancers as cancers that originated from structures between the esophagus and rectum, including the hepatobiliarypancreatic system. We excluded studies that did not report original data, did not have HR or confidence interval for the survival analysis, lacked NLR, were duplicates, or presented redundant patient populations

\section{Database search}

We identified published studies from PubMed (National Library of Medicine), ScienceDirect (Elsevier), Scopus (Elsevier), EMBASE (Embase.com), and Cochrane Library (Wiley Interscience) electronic databases from inception to March 3 2016. There were no language restrictions. We developed a detailed search strategy specific for each electronic database to enhance our search results (online Supplement). EndNote X7 was used for de-duplication (EndNote, Thomson Reuters).

\section{The review process/reviewer}

Six reviewers independently assessed articles in 3 pairs (E.S., and A.M.B.; J.R.H., and N.A.B.L.; L.G.M and K.D.R.). The titles and abstracts (if available) were screened. Full-text copies for all potentially relevant articles were reviewed independently by at least 2 reviewers for inclusion and data collection. A third reviewer reconciled disagreements. Non-English articles had one reviewer, facilitated by language interpreters. For data extraction we used pre-made data entry sheets with details found in Supplementary Methods of the Supplement.

\section{Risk of bias}

For the complete methods of our risk of bias analysis, see eMethods. In short, all papers were analyzed for bias using A Cochrane Risk of Bias Assessment Tool: For Non-Randomized Studies of Interventions (ACROBAT-NRSI) [40]. Additionally, random effect Begg's funnel plot and Egger's linear regression were created to evaluate publication bias.

\section{Statistical analysis}

All analyses were conducted by using STATA statistical software, v 14 (Stata Corp LP, College Station, TX, USA). Hazard ratios and corresponding 95\% confidence intervals were collected for each study and then combined using the random effect (MantelHaenszel) method. Summary hazards ratio estimates were provided for each subgroup and full collection of studies. Hazard ratios compared patients with a NLR lower than the cutoff with patients that had a NLR higher than the cutoff value. The NLR cutoff value was unique in each study. Heterogeneity was assessed by the Q and I-squared statistics, calculated for each subgroup and for the full collection of studies. Forest plots were created to show primary and secondary endpoints. Meta regression was created to explore the heterogeneity between OS and NLR cutoff values. Wilcoxon rank sum test evaluated difference of NLR cutoff between subgroups.

\section{CONFLICTS OF INTEREST}

The author(s) have no proprietary or commercial interest in any materials discussed in this article.

\section{REFERENCES}

1. Zahorec R. Ratio of neutrophil to lymphocyte counts - rapid and simple parameter of systemic inflammation and stress in critically ill. [Article in English, Slovak]. Bratisl Lek Listy. 2001;102:5-14.

2. Mantovani A, Allavena P, Sica A, Balkwill F. Cancerrelated inflammation. Nature. 2008;454:436-444.

3. Hanahan D, Weinberg RA. Hallmarks of cancer: the next generation. Cell. 2011;144:646-674. 
4. Chiang SF, Hung HY, Tang R, Changchien CR, Chen JS, You YT, Chiang JM, Lin JR. Can neutrophil-to-lymphocyte ratio predict the survival of colorectal cancer patients who have received curative surgery electively? Int J Colorectal Dis. 2012;27:1347-1357.

5. Goldstein D, El-Maraghi RH, Hammel P, Heinemann V, Kunzmann V, Sastre J, Scheithauer W, Siena S, Tabernero J, Teixeira L, Tortora G, Van Laethem JL, Young R, et al. nab-Paclitaxel plus gemcitabine for metastatic pancreatic cancer: long-term survival from a phase III trial. J Natl Cancer Inst. 2015;107

6. Templeton AJ, McNamara MG, Seruga B, Vera-Badillo FE, Aneja P, Ocana A, Leibowitz-Amit R, Sonpavde G, Knox JJ, Tran B, Tannock IF, Amir E. Prognostic role of neutrophil-to-lymphocyte ratio in solid tumors: a systematic review and meta-analysis. J Natl Cancer Inst. 2014;106:dju124.

7. Cho S, Cho H, Nam A, Kim HY, Choi YS, Park KH, Cho DJ, Lee BS. Neutrophil-to-lymphocyte ratio as an adjunct to CA-125 for the diagnosis of endometriosis. Fertil Steril 2008;90:2073-2079.

8. Muhmmed Suliman MA, Bahnacy Juma AA, Ali Almadhani AA, Pathare AV, Alkindi SS, Uwe Werner F. Predictive value of neutrophil to lymphocyte ratio in outcomes of patients with acute coronary syndrome. Arch Med Res. 2010;41:618-622.

9. Kuyumcu ME, Yesil Y, Ozturk ZA, Kizilarslanoglu C, Etgul S, Halil M, Ulger Z, Cankurtaran M, Ariogul S. The evaluation of neutrophil-lymphocyte ratio in Alzheimer's disease. Dement Geriatr Cogn Disord. 2012;34:69-74.

10. McGary CT, Miele ME, Welch DR. Highly metastatic $13762 \mathrm{NF}$ rat mammary adenocarcinoma cell clones stimulate bone marrow by secretion of granulocytemacrophage colony-stimulating factor/interleukin-3 activity. Am J Pathol. 1995;147:1668-1681.

11. Li W, Zhang X, Chen Y, Xie Y, Liu J, Feng Q, Wang Y, Yuan W, Ma J. G-CSF is a key modulator of MDSC and could be a potential therapeutic target in colitis-associated colorectal cancers. Protein Cell. 2016;7:130-140.

12. Hashimoto T, Ohno Y, Nakashima J, Gondo T, Ohori M, Tachibana M. Clinical significance of preoperative peripheral blood neutrophil count in patients with nonmetastatic upper urinary tract carcinoma. World J Urol. 2013;31:953-958.

13. Shi Q, Abbruzzese JL, Huang S, Fidler IJ, Xiong Q, Xie $\mathrm{K}$. Constitutive and inducible interleukin 8 expression by hypoxia and acidosis renders human pancreatic cancer cells more tumorigenic and metastatic. Clin Cancer Res. 1999;5:3711-3721

14. Fridlender ZG, Sun J, Kim S, Kapoor V, Cheng G, Ling L, Worthen GS, Albelda SM. Polarization of tumor-associated neutrophil phenotype by TGF-beta: "N1" versus "N2" TAN. Cancer Cell. 2009;16:183-194.

15. van Zijl F, Mair M, Csiszar A, Schneller D, Zulehner G,
Huber H, Eferl R, Beug H, Dolznig H, Mikulits W. Hepatic tumor-stroma crosstalk guides epithelial to mesenchymal transition at the tumor edge; Oncogene. 2009; 28:40224033.

16. Hawinkels LJ, Zuidwijk K, Verspaget HW, de JongeMuller ES, van Duijn W, Ferreira V, Fontijn RD, David G, Hommes DW, Lamers CB, Sier CF. VEGF release by MMP-9 mediated heparan sulphate cleavage induces colorectal cancer angiogenesis. Eur J Cancer. 2008;44:1904-1913.

17. Knaapen AM, Gungor N, Schins RP, Borm PJ, Van Schooten FJ. Neutrophils and respiratory tract DNA damage and mutagenesis: a review. Mutagenesis. 2006;21:225-236.

18. He G, Zhang H, Zhou J, Wang B, Chen Y, Kong Y, Xie X, Wang X, Fei R, Wei L, Chen H, Zeng H. Peritumoural neutrophils negatively regulate adaptive immunity via the PD-L1/PD-1 signalling pathway in hepatocellular carcinoma. J Exp Clin Cancer Res. 2015;34:141.

19. Sandel MH, Dadabayev AR, Menon AG, Morreau H, Melief CJ, Offringa R, van der Burg SH, Janssen-van Rhijn CM, Ensink NG, Tollenaar RA, van de Velde CJ, Kuppen PJ. Prognostic value of tumor-infiltrating dendritic cells in colorectal cancer: role of maturation status and intratumoral localization. Clin Cancer Res. 2005;11:2576-2582.

20. Schumacher K, Haensch W, Roefzaad C, Schlag PM. Prognostic significance of activated $\mathrm{CD} 8(+) \mathrm{T}$ cell infiltrations within esophageal carcinomas. Cancer Res. 2001;61:3932-3936.

21. Zhang L, Conejo-Garcia JR, Katsaros D, Gimotty PA, Massobrio M, Regnani G, Makrigiannakis A, Gray H, Schlienger K, Liebman MN, Rubin SC, Coukos G. Intratumoral $\mathrm{T}$ cells, recurrence, and survival in epithelial ovarian cancer. N Engl J Med. 2003;348:203-213.

22. Brichard VG, Lejeune D. GSK's antigen-specific cancer immunotherapy programme. pilot results leading to Phase III clinical development. Vaccine. 2007;25 Suppl 2:B61-71.

23. Khong HT, Restifo NP. Natural selection of tumor variants in the generation of "tumor escape" phenotypes. Nat Immunol. 2002;3:999-1005.

24. Huber C, Bobek N, Kuball J, Thaler S, Hoffarth S, Theobald M, Schuler M. Inhibitors of apoptosis confer resistance to tumour suppression by adoptively transplanted cytotoxic T-lymphocytes in vitro and in vivo. Cell Death Differ. 2005; 12:317-325.

25. Catalan E, Charni S, Jaime P, Aguilo JI, Enriquez JA, Naval J, Pardo J, Villalba M, Anel A. MHC-I modulation due to changes in tumor cell metabolism regulates tumor sensitivity to CTL and NK cells. Oncoimmunology. 2015;4:e985924.

26. Mizukami Y, Kono K, Maruyama T, Watanabe M, Kawaguchi Y, Kamimura K, Fujii H. Downregulation of HLA Class I molecules in the tumour is associated with a poor prognosis in patients with oesophageal squamous cell carcinoma. Br J Cancer. 2008;99:1462-1467. 
27. Stewart CA, Metheny H, Iida N, Smith L, Hanson M, Steinhagen F, Leighty RM, Roers A, Karp CL, Muller $\mathrm{W}$, Trinchieri G. Interferon-dependent IL-10 production by Tregs limits tumor Th17 inflammation. J Clin Invest. 2013;123:4859-4874.

28. Mariotto AB, Yabroff KR, Shao Y, Feuer EJ, Brown ML. Projections of the cost of cancer care in the United States: 2010-2020. J Natl Cancer Inst. 2011;103:117-128.

29. Laudicella M, Walsh B, Burns E, Smith PC. Cost of care for cancer patients in England: evidence from population-based patient-level data. Br J Cancer. 2016;114:1286-1292.

30. Kriza C, Emmert M, Wahlster P, Niederlander C, Kolominsky-Rabas P. Cost of illness in colorectal cancer: an international review. Pharmacoeconomics. 2013;31:577588.

31. Li TY, Hsieh JS, Lee KT, Hou MF, Wu CL, Kao HY, Shi HY. Cost trend analysis of initial cancer treatment in Taiwan. PLoS One. 2014;9:e108432.

32. Wilmott JS, Long GV, Howle JR, Haydu LE, Sharma RN, Thompson JF, Kefford RF, Hersey P, Scolyer RA. Selective BRAF inhibitors induce marked T-cell infiltration into human metastatic melanoma. Clin Cancer Res. 2012;18:1386-1394.

33. Warren JL, Yabroff KR, Meekins A, Topor M, Lamont EB, Brown ML. Evaluation of trends in the cost of initial cancer treatment. J Natl Cancer Inst. 2008;100:888-897.

34. Chalkidou K, Marquez P, Dhillon PK, Teerawattananon Y, Anothaisintawee T, Gadelha CA, Sullivan R. Evidenceinformed frameworks for cost-effective cancer care and prevention in low, middle, and high-income countries. Lancet Oncol. 2014;15:e119-131.

35. Tamhane UU, Aneja S, Montgomery D, Rogers EK, Eagle KA, Gurm HS. Association between admission neutrophil to lymphocyte ratio and outcomes in patients with acute coronary syndrome. Am J Cardiol. 2008;102:653-657.

36. Gary T, Pichler M, Belaj K, Hafner F, Gerger A, Froehlich H, Eller P, Pilger E, Brodmann M. Neutrophilto-lymphocyte ratio and its association with critical limb ischemia in PAOD patients. PLoS One. 2013;8:e56745.

37. Azab B, Daoud J, Naeem FB, Nasr R, Ross J, Ghimire P, Siddiqui A, Azzi N, Rihana N, Abdallah M, Patel P, Kleiner M, El-Sayegh S. Neutrophil-to-lymphocyte ratio as a predictor of worsening renal function in diabetic patients (3-year follow-up study). Ren Fail. 2012;34:571-576.

38. Biyik M, Ucar R, Solak Y, Gungor G, Polat I, Gaipov A, Cakir OO, Ataseven H, Demir A, Turk S, Polat H. Blood neutrophil-to-lymphocyte ratio independently predicts survival in patients with liver cirrhosis. Eur J Gastroenterol Hepatol. 2013;25:435-441.

39. Stroup DF, Berlin JA, Morton SC, Olkin I, Williamson GD, Rennie D, Moher D, Becker BJ, Sipe TA, Thacker SB. Meta-analysis of observational studies in epidemiology: a proposal for reporting. Meta-analysis Of Observational Studies in Epidemiology (MOOSE) group. Jama.
$2000 ; 283: 2008-2012$

40. Sterne J, Higgins J, Reeves B. A Cochrane Risk Of Bias Assessment Tool: for Non-Randomized Studies of Interventions (ACROBAT-NRSI), Version 1.0.0, 24 September 2014. Available from http://www.riskofbias.info [accessed July 2015]. 2014

41. Halazun KJ, Aldoori A, Malik HZ, Al-Mukhtar A, Prasad KR, Toogood GJ, Lodge JP. Elevated preoperative neutrophil to lymphocyte ratio predicts survival following hepatic resection for colorectal liver metastases. Eur J Surg Oncol. 2008;34:55-60.

42. Halazun KJ, Hardy MA, Rana AA, Woodland DC 4th, Luyten EJ, Mahadev S, Witkowski P, Siegel AB, Brown RS Jr, Emond JC. Negative impact of neutrophillymphocyte ratio on outcome after liver transplantation for hepatocellular carcinoma. Ann Surg. 2009;250:141-151.

43. Kishi Y, Kopetz S, Chun YS, Palavecino M, Abdalla EK, Vauthey JN. Blood neutrophil-to-lymphocyte ratio predicts survival in patients with colorectal liver metastases treated with systemic chemotherapy. Ann Surg Oncol. 2009; 16:614-622.

44. Neal CP, Mann CD, Sutton CD, Garcea G, Ong SL, Steward WP, Dennison AR, Berry DP. Evaluation of the prognostic value of systemic inflammation and socioeconomic deprivation in patients with resectable colorectal liver metastases. Eur J Cancer. 2009;45:56-64.

45. An X, Ding PR, Li YH, Wang FH, Shi YX, Wang ZQ, He YJ, Xu RH, Jiang WQ. Elevated neutrophil to lymphocyte ratio predicts survival in advanced pancreatic cancer. Biomarkers. 2010;15:516-522.

46. Ding PR, An X, Zhang RX, Fang YJ, Li LR, Chen G, Wu XJ, Lu ZH, Lin JZ, Kong LH, Wan DS, Pan ZZ. Elevated preoperative neutrophil to lymphocyte ratio predicts risk of recurrence following curative resection for stage IIA colon cancer. Int J Colorectal Dis. 2010;25:1427-1433.

47. Liu H, Liu G, Bao Q, Sun W, Bao H, Bi L, Wen W, Liu Y, Wang Z, Yin X, Bai Y, Hu X: The baseline ratio of neutrophils to lymphocytes is associated with patient prognosis in rectal carcinoma. J Gastrointest Cancer. 2010;41:116-120.

48. Shimada H, Takiguchi N, Kainuma O, Soda H, Ikeda A, Cho A, Miyazaki A, Gunji H, Yamamoto H, Nagata M. High preoperative neutrophil-lymphocyte ratio predicts poor survival in patients with gastric cancer. Gastric Cancer. 2010;13:170-176.

49. Ubukata H, Motohashi G, Tabuchi T, Nagata H, Konishi $\mathrm{S}$. Evaluations of interferon-gamma/interleukin-4 ratio and neutrophil/lymphocyte ratio as prognostic indicators in gastric cancer patients. J Surg Oncol. 2010;102:742-747.

50. Chua W, Charles KA, Baracos VE, Clarke SJ. Neutrophil/ lymphocyte ratio predicts chemotherapy outcomes in patients with advanced colorectal cancer. $\mathrm{Br} \mathrm{J}$ Cancer. 2011;104:1288-1295.

51. Huang ZL, Luo J, Chen MS, Li JQ, Shi M. Blood 
neutrophil-to-lymphocyte ratio predicts survival in patients with unresectable hepatocellular carcinoma undergoing transarterial chemoembolization. J Vasc Interv Radiol. 2011;22:702-709.

52. Hung HY, Chen JS, Yeh CY, Changchien CR, Tang R, Hsieh PS, Tasi WS, You JF, You YT, Fan CW, Wang JY, Chiang JM. Effect of preoperative neutrophil-lymphocyte ratio on the surgical outcomes of stage II colon cancer patients who do not receive adjuvant chemotherapy. Int J Colorectal Dis. 2011;26:1059-1065.

53. Jung MR, Park YK, Jeong O, Seon JW, Ryu SY, Kim DY, Kim YJ. Elevated preoperative neutrophil to lymphocyte ratio predicts poor survival following resection in late stage gastric cancer. J Surg Oncol. 2011;104:504-510.

54. Miyata H, Yamasaki M, Kurokawa Y, Takiguchi S, Nakajima K, Fujiwara Y, Mori M, Doki Y. Prognostic value of an inflammation-based score in patients undergoing preoperative chemotherapy followed by surgery for esophageal cancer. Exp Ther Med. 2011;2:879-885.

55. Sharaiha RZ, Halazun KJ, Mirza F, Port JL, Lee PC, Neugut AI, Altorki NK, Abrams JA. Elevated preoperative neutrophil:lymphocyte ratio as a predictor of postoperative disease recurrence in esophageal cancer. Ann Surg Oncol. 2011;18:3362-3369.

56. Wang GY, Yang Y, Li H, Zhang J, Jiang N, Li MR, Zhu HB, Zhang Q, Chen GH. A scoring model based on neutrophil to lymphocyte ratio predicts recurrence of HBV-associated hepatocellular carcinoma after liver transplantation. PLoS One. 2011;6:e25295.

57. Wang GY, Yang Y, Zhang Q, Li H, Chen GZ, Yi SH, Xu C, Wang GS, Zhang J, Yi HM, Jiang N, Fu BS, Zhao H, et al. Preoperative neutrophil-lymphocyte ratio as a prognostic predictor after liver transplantation for hepatocellular carcinoma. [Article in Chinese]. Zhonghua Yi Xue Za Zhi. 2011;91:1519-1522.

58. Carruthers R, Tho LM, Brown J, Kakumanu S, McCartney $\mathrm{E}, \mathrm{McDonald}$ AC. Systemic inflammatory response is a predictor of outcome in patients undergoing preoperative chemoradiation for locally advanced rectal cancer. Colorectal Dis. 2012;14:e701-707.

59. Chen TM, Lin CC, Huang PT, Wen CF. Neutrophilto-lymphocyte ratio associated with mortality in early hepatocellular carcinoma patients after radiofrequency ablation. J Gastroenterol Hepatol. 2012;27:553-561.

60. Jeong JH, Lim SM, Yun JY, Rhee GW, Lim JY, Cho JY, Kim YR. Comparison of two inflammation-based prognostic scores in patients with unresectable advanced gastric cancer. Oncology. 2012;83:292-299.

61. Kaneko M, Nozawa H, Sasaki K, Hongo K, Hiyoshi M, Tada N, Murono K, Nirei T, Kawai K, Sunami E, Tsuno $\mathrm{NH}$, Kitayama J. Elevated neutrophil to lymphocyte ratio predicts poor prognosis in advanced colorectal cancer patients receiving oxaliplatin-based chemotherapy. Oncology. 2012;82:261-268.
62. Kim YH, Choi WJ. The effectiveness of postoperative neutrophils to lymphocytes ratio in predicting long-term recurrence after stomach cancer surgery. J Korean Surg Soc. 2012;83:352-359.

63. Kwon HC, Kim SH, Oh SY, Lee S, Lee JH, Choi HJ, Park KJ, Roh MS, Kim SG, Kim HJ. Clinical significance of preoperative neutrophil-lymphocyte versus plateletlymphocyte ratio in patients with operable colorectal cancer. Biomarkers. 2012;17:216-222.

64. Pinato DJ, Stebbing J, Ishizuka M, Khan SA, Wasan HS, North BV, Kubota K, Sharma R. A novel and validated prognostic index in hepatocellular carcinoma: the inflammation based index (IBI). J Hepatol. 2012;57:10131020.

65. Wang DS, Luo HY, Qiu MZ, Wang ZQ, Zhang DS, Wang $\mathrm{FH}, \mathrm{Li} \mathrm{YH}, \mathrm{Xu} \mathrm{RH}$. Comparison of the prognostic values of various inflammation based factors in patients with pancreatic cancer. Med Oncol. 2012;29:3092-3100.

66. Wang DS, Ren C, Qiu MZ, Luo HY, Wang ZQ, Zhang DS, Wang FH, Li YH, Xu RH. Comparison of the prognostic value of various preoperative inflammation-based factors in patients with stage III gastric cancer. Tumour Biol. 2012;33:749-756.

67. Zhang Y, Peng Z, Chen M, Liu F, Huang J, Xu L. Elevated neutrophil to lymphocyte ratio might predict poor prognosis for colorectal liver metastasis after percutaneous radiofrequency ablation. Int J Hyperthermia. 2012;28:132140.

68. Absenger G, Szkandera J, Stotz M, Postlmayr U, Pichler M, Ress AL, Schaberl-Moser R, Loibner H, Samonigg H, Gerger A. Preoperative Neutrophil-to-Lymphocyte Ratio Predicts Clinical Outcome in Patients with Stage II and III Colon Cancer. Anticancer Res. 2013;33:4591-4594.

69. Feng JF, Huang Y, Liu JS. Combination of neutrophil lymphocyte ratio and platelet lymphocyte ratio is a useful predictor of postoperative survival in patients with esophageal squamous cell carcinoma. Onco Targets Ther. 2013;6:1605-1612.

70. Fu SJ, Shen SL, Li SQ, Hua YP, Hu WJ, Liang LJ, Peng BG. Prognostic value of preoperative peripheral neutrophilto-lymphocyte ratio in patients with $\mathrm{HBV}$-associated hepatocellular carcinoma after radical hepatectomy. Med Oncol. 2013;30:721.

71. Guthrie GJ, Roxburgh CS, Farhan-Alanie OM, Horgan PG, McMillan DC. Comparison of the prognostic value of longitudinal measurements of systemic inflammation in patients undergoing curative resection of colorectal cancer. Br J Cancer. 2013;109:24-28.

72. Lee DY, Hong SW, Chang YG, Lee WY, Lee B. Clinical significance of preoperative inflammatory parameters in gastric cancer patients. J Gastric Cancer. 2013;13:111-116.

73. Lee S, Oh SY, Kim SH, Lee JH, Kim MC, Kim KH, Kim HJ. Prognostic significance of neutrophil lymphocyte ratio and platelet lymphocyte ratio in advanced gastric cancer 
patients treated with FOLFOX chemotherapy. BMC Cancer. 2013;13:350.

74. Limaye AR, Clark V, Soldevila-Pico C, Morelli G, Suman A, Firpi R, Nelson DR, Cabrera R. Neutrophil-lymphocyte ratio predicts overall and recurrence-free survival after liver transplantation for hepatocellular carcinoma. Hepatol Res. 2013;43:757-764.

75. Mallappa S, Sinha A, Gupta S, Chadwick SJ. Preoperative neutrophil to lymphocyte ratio $>5$ is a prognostic factor for recurrent colorectal cancer. Colorectal Dis. 2013;15:323328.

76. Motomura T, Shirabe K, Mano Y, Muto J, Toshima T, Umemoto Y, Fukuhara T, Uchiyama H, Ikegami T, Yoshizumi T, Soejima Y, Maehara Y. Neutrophillymphocyte ratio reflects hepatocellular carcinoma recurrence after liver transplantation via inflammatory microenvironment. J Hepatol. 2013;58:58-64.

77. Oh BS, Jang JW, Kwon JH, You CR, Chung KW, Kay CS, Jung HS, Lee S. Prognostic value of C-reactive protein and neutrophil-to-lymphocyte ratio in patients with hepatocellular carcinoma. BMC Cancer. 2013;13:78.

78. Perez DR, Baser RE, Cavnar MJ, Balachandran VP, Antonescu CR, Tap WD, Strong VE, Brennan MF, Coit DG, Singer S, Dematteo RP. Blood neutrophil-tolymphocyte ratio is prognostic in gastrointestinal stromal tumor. Ann Surg Oncol. 2013;20:593-599.

79. Shibutani M, Maeda K, Nagahara H, Noda E, Ohtani H, Nishiguchi Y, Hirakawa K. A high preoperative neutrophil-to-lymphocyte ratio is associated with poor survival in patients with colorectal cancer. Anticancer Res. 2013;33:3291-3294.

80. Stotz M, Gerger A, Eisner F, Szkandera J, Loibner H, Ress AL, Kornprat P, AlZoughbi W, Seggewies FS, Lackner C, Stojakovic T, Samonigg H, Hoefler G, et al. Increased neutrophil-lymphocyte ratio is a poor prognostic factor in patients with primary operable and inoperable pancreatic cancer. Br J Cancer. 2013;109:416-421.

81. Teo M, Mohd Sharial MS, McDonnell F, Conlon KC, Ridgway PF, McDermott RS. Prognostic role of neutrophilto-lymphocyte ratio in advanced pancreatic ductal adenocarcinoma: impact of baseline fluctuation and changes during chemotherapy. Tumori. 2013;99:516-522.

82. Aino H, Sumie S, Niizeki T, Kuromatsu R, Tajiri N, Nakano M, Satani M, Yamada S, Okamura S, Shimose S, Sumie H, Torimura T, Sata M. Clinical characteristics and prognostic factors for advanced hepatocellular carcinoma with extrahepatic metastasis. Mol Clin Oncol. 2014;2:393398.

83. Atila K, Arslan NC, Derici S, Canda AE, Sagol O, Oztop I, Bora S. Neutrophil-to-lymphocyte ratio: could it be used in the clinic as prognostic marker for gastrointestinal stromal tumor? Hepatogastroenterology. 2014;61:1649-1653.

84. Cho IR, Park JC, Park CH, Jo JH, Lee HJ, Kim S, Shim CN, Lee H, Shin SK, Lee SK, Lee YC. Pre-treatment neutrophil to lymphocyte ratio as a prognostic marker to predict chemotherapeutic response and survival outcomes in metastatic advanced gastric cancer. Gastric Cancer. 2014;17:703-710.

85. Choi KW, Hong SW, Chang YG, Lee WY, Lee B, Paik IW, Lee H. Inflammation-based score (Glasgow prognostic score) as an independent prognostic factor in colorectal cancer patients. Ann Surg Treat Res. 2014;86:309-313.

86. Forrest R, Guthrie GJ, Orange C, Horgan PG, McMillan DC, Roxburgh CS. Comparison of visual and automated assessment of tumour inflammatory infiltrates in patients with colorectal cancer. Eur J Cancer. 2014;50:544-552.

87. Ishizuka M, Oyama Y, Abe A, Kubota K. Combination of platelet count and neutrophil to lymphocyte ratio is a useful predictor of postoperative survival in patients undergoing surgery for gastric cancer. J Surg Oncol. 2014;110:935-941.

88. Jiang N, Deng JY, Liu Y, Ke B, Liu HG, Liang H. The role of preoperative neutrophil-lymphocyte and plateletlymphocyte ratio in patients after radical resection for gastric cancer. Biomarkers. 2014;19:444-451.

89. Kim IY, You SH, Kim YW. Neutrophil-lymphocyte ratio predicts pathologic tumor response and survival after preoperative chemoradiation for rectal cancer. BMC Surg. 2014;14:94.

90. Kubo T, Ono S, Ueno H, Shinto E, Yamamoto J, Hase K. Impact of the perioperative neutrophil-to-lymphocyte ratio on the long-term survival following an elective resection of colorectal carcinoma. Int J Colorectal Dis. 2014;29:10911099.

91. Li X, Chen ZH, Ma XK, Chen J, Wu DH, Lin Q, Dong M, Wei L, Wang TT, Ruan DY, Lin ZX, Xing YF, Deng Y, et al. Neutrophil-to-lymphocyte ratio acts as a prognostic factor for patients with advanced hepatocellular carcinoma. Tumour Biol. 2014;35:11057-11063.

92. Liao W, Zhang J, Zhu Q, Qin L, Yao W, Lei B, Shi W, Yuan S, Tahir SA, Jin J, He S. Preoperative Neutrophilto-Lymphocyte Ratio as a New Prognostic Marker in Hepatocellular Carcinoma after Curative Resection. Transl Oncol. 2014;7:248-255.

93. Martin HL, Ohara K, Kiberu A, Van Hagen T, Davidson A, Khattak MA. Prognostic value of systemic inflammationbased markers in advanced pancreatic cancer. Intern Med J. 2014;44:676-682.

94. McNamara MG, Templeton AJ, Maganti M, Walter T, Horgan AM, McKeever L, Min T, Amir E, Knox JJ. Neutrophil/lymphocyte ratio as a prognostic factor in biliary tract cancer. Eur J Cancer. 2014;50:1581-1589.

95. Mohri Y, Tanaka K, Ohi M, Saigusa S, Yasuda H, Toiyama $\mathrm{Y}$, Araki T, Inoue Y, Kusunoki M. Identification of prognostic factors and surgical indications for metastatic gastric cancer. BMC Cancer. 2014;14:409.

96. Na GH, Kim DG, Han JH, Kim EY, Lee SH, Hong TH, You YK. Inflammatory markers as selection criteria of hepatocellular carcinoma in living-donor liver 
transplantation. World J Gastroenterol. 2014;20:6594-6601.

97. Neofytou K, Smyth EC, Giakoustidis A, Khan AZ, Cunningham D, Mudan S. Elevated platelet to lymphocyte ratio predicts poor prognosis after hepatectomy for liveronly colorectal metastases, and it is superior to neutrophil to lymphocyte ratio as an adverse prognostic factor. Med Oncol. 2014;31:239.

98. Ozdemir Y, Akin ML, Sucullu I, Balta AZ, Yucel E. Pretreatment neutrophil/lymphocyte ratio as a prognostic aid in colorectal cancer. Asian Pac J Cancer Prev. 2014; 15:2647-2650.

99. Paik KY, Lee IK, Lee YS, Sung NY, Kwon TS. Clinical implications of systemic inflammatory response markers as independent prognostic factors in colorectal cancer patients. Cancer Res Treat. 2014;46:65-73.

100. Shen L, Zhang H, Liang L, Li G, Fan M, Wu Y, Zhu J, Zhang Z. Baseline neutrophil-lymphocyte ratio $(>/=2.8)$ as a prognostic factor for patients with locally advanced rectal cancer undergoing neoadjuvant chemoradiation. Radiat Oncol. 2014;9:295.

101. Tanaka H, Muguruma K, Toyokawa T, Kubo N, Ohira M, Hirakawa K. Differential impact of the neutrophillymphocyte ratio on the survival of patients with stage IV gastric cancer. Dig Surg. 2014;31:327-333.

102. Terashima T, Yamashita T, Iida N, Nakagawa H, Arai K, Kitamura K, Kagaya T, Sakai Y, Mizukoshi E, Honda M, Kaneko S. Blood neutrophil to lymphocyte ratio as a predictor in patients with advanced hepatocellular carcinoma treated with hepatic arterial infusion chemotherapy. Hepatol Res. 2014.

103. Toh E, Wilson J, Sebag-Montefiore D, Botterill I. Neutrophil:lymphocyte ratio as a simple and novel biomarker for prediction of locoregional recurrence after chemoradiotherapy for squamous cell carcinoma of the anus. Colorectal Dis. 2014;16:O90-97.

104. Wang Q, Yang Y, Zhang YP, Zou Z, Qian X, Liu B, Wei J. Prognostic value of carbohydrate tumor markers and inflammation-based markers in metastatic or recurrent gastric cancer. Med Oncol. 2014;31:289.

105. Wu XS, Shi LB, Li ML, Ding Q, Weng H, Wu WG, Cao Y, Bao RF, Shu YJ, Ding QC, Mu JS, Gu J, Dong P, et al. Evaluation of two inflammation-based prognostic scores in patients with resectable gallbladder carcinoma. Ann Surg Oncol. 2014;21:449-457.

106. Xiao GQ, Yan L, Yang J. How to select suitable hepatocellular carcinoma for liver transplantation by preoperative neutrophil-lymphocyte ratio. Hepatogastroenterology. 2014;61:2077-2083.

107. Xu X, Chen W, Zhang L, Miao R, Zhou Y, Wan Y, Dong Y, Liu C. Prognostic significance of neutrophil to lymphocyte ratio in patients with hepatocellular carcinoma after transcatheter arterial chemoembolization. Chin Med J (Engl). 2014;127:4204-4209.

108. Xue P, Kanai M, Mori Y, Nishimura T, Uza N, Kodama Y,
Kawaguchi Y, Takaori K, Matsumoto S, Uemoto S, Chiba T. Neutrophil-to-lymphocyte ratio for predicting palliative chemotherapy outcomes in advanced pancreatic cancer patients. Cancer Med. 2014;3:406-415.

109. Yamamura K, Sugimoto H, Kanda M, Yamada S, Nomoto S, Nakayama G, Fujii T, Koike M, Fujiwara M, Kodera Y. Comparison of inflammation-based prognostic scores as predictors of tumor recurrence in patients with hepatocellular carcinoma after curative resection. J Hepatobiliary Pancreat Sci. 2014;21:682-688.

110. Ying HQ, Deng QW, He BS, Pan YQ, Wang F, Sun HL, Chen J, Liu X, Wang SK. The prognostic value of preoperative NLR, d-NLR, PLR and LMR for predicting clinical outcome in surgical colorectal cancer patients. Med Oncol. 2014;31:305.

111. Yoo EJ, Park JC, Kim EH, Park CH, Shim CN, Lee HJ, Chung HS, Lee H, Shin SK, Lee SK, Lee CG, Lee YC. Prognostic value of neutrophil-to-lymphocyte ratio in patients treated with concurrent chemoradiotherapy for locally advanced oesophageal cancer. Dig Liver Dis. 2014;46:846-853.

112. Yuan D, Zhu K, Li K, Yan R, Jia Y, Dang C. The preoperative neutrophil-lymphocyte ratio predicts recurrence and survival among patients undergoing R0 resections of adenocarcinomas of the esophagogastric junction. J Surg Oncol. 2014;110:333-340.

113. Zhang J, Gong F, Li L, Zhao M, Song J. Diabetes mellitus and the neutrophil to lymphocyte ratio predict overall survival in non-viral hepatocellular carcinoma treated with transarterial chemoembolization. Oncol Lett. 2014;7:17041710.

114. Ben Q, An W, Wang L, Wang W, Yu L, Yuan Y. Validation of the pretreatment neutrophil-lymphocyte ratio as a predictor of overall survival in a cohort of patients with pancreatic ductal adenocarcinoma. Pancreas. 2015;44:471477.

115. Chen ZY, Raghav K, Lieu CH, Jiang ZQ, Eng C, Vauthey JN, Chang GJ, Qiao W, Morris J, Hong D, Hoff P, Tran $\mathrm{H}$, Menter DG, et al. Cytokine profile and prognostic significance of high neutrophil-lymphocyte ratio in colorectal cancer. Br J Cancer. 2015; 112:1088-1097.

116. Chen Q, Yang LX, Li XD, Yin D, Shi SM, Chen EB, Yu L, Zhou ZJ, Zhou SL, Shi YH, Fan J, Zhou J, Dai Z. The elevated preoperative neutrophil-to-lymphocyte ratio predicts poor prognosis in intrahepatic cholangiocarcinoma patients undergoing hepatectomy. Tumour Biol. 2015;36:5283-5289.

117. Choi WJ, Cleghorn MC, Jiang H, Jackson TD, Okrainec A, Quereshy FA. Preoperative Neutrophil-to-Lymphocyte Ratio is a Better Prognostic Serum Biomarker than Plateletto-Lymphocyte Ratio in Patients Undergoing Resection for Nonmetastatic Colorectal Cancer. Ann Surg Oncol. 2015;22 Suppl 3:S603-613.

118. Del Prete M, Giampieri R, Loupakis F, Prochilo T, Salvatore L, Faloppi L, Bianconi M, Bittoni A, Aprile 
G, Zaniboni A, Falcone A, Scartozzi M, Cascinu S. Prognostic clinical factors in pretreated colorectal cancer patients receiving regorafenib: implications for clinical management. Oncotarget. 2015;6:33982-33992. doi: 10.18632/oncotarget.5053.

119. Deng Q, He B, Liu X, Yue J, Ying H, Pan Y, Sun H, Chen J, Wang F, Gao T, Zhang L, Wang S. Prognostic value of pre-operative inflammatory response biomarkers in gastric cancer patients and the construction of a predictive model. J Transl Med. 2015;13:66.

120. Duan H, Zhang X, Wang FX, Cai MY, Ma GW, Yang H, Fu JH, Tan ZH, Meng YQ, Fu XY, Ma QL, Lin P. Prognostic role of neutrophil-lymphocyte ratio in operable esophageal squamous cell carcinoma. World J Gastroenterol. 2015;21:5591-5597.

121. Fan W, Zhang Y, Wang Y, Yao X, Yang J, Li J. Neutrophil-to-lymphocyte and platelet-to-lymphocyte ratios as predictors of survival and metastasis for recurrent hepatocellular carcinoma after transarterial chemoembolization. PLoS One. 2015;10:e0119312.

122. Galizia G, Lieto E, Zamboli A, De Vita F, Castellano P, Romano C, Auricchio A, Cardella F, De Stefano L, Orditura M. Neutrophil to lymphocyte ratio is a strong predictor of tumor recurrence in early colon cancers: A propensity score-matched analysis. Surgery. 2015;158:112-120.

123. Gao F, Li X, Geng M, Ye X, Liu H, Liu Y, Wan G, Wang X. Pretreatment neutrophil-lymphocyte ratio: an independent predictor of survival in patients with hepatocellular carcinoma. Medicine (Baltimore). 2015;94:e639.

124. Ghanim B, Schweiger T, Jedamzik J, Glueck O, Glogner C, Lang G, Klepetko W, Hoetzenecker K. Elevated inflammatory parameters and inflammation scores are associated with poor prognosis in patients undergoing pulmonary metastasectomy for colorectal cancer. Interact Cardiovasc Thorac Surg. 2015;21:616-623.

125. Giakoustidis A, Neofytou K, Khan AZ, Mudan S. Neutrophil to lymphocyte ratio predicts pattern of recurrence in patients undergoing liver resection for colorectal liver metastasis and thus the overall survival. J Surg Oncol. 2015;111:445-450.

126. Giordano G, Febbraro A, Tomaselli E, Sarnicola ML, Parcesepe P, Parente D, Forte N, Fabozzi A, Remo A, Bonetti A, Manfrin E, Ghasemi S, Ceccarelli M, et al. Cancer-related CD15/FUT4 overexpression decreases benefit to agents targeting EGFR or VEGF acting as a novel RAF-MEK-ERK kinase downstream regulator in metastatic colorectal cancer. J Exp Clin Cancer Res. 2015;34:108.

127. Hsu JT, Liao CK, Le PH, Chen TH, Lin CJ, Chen JS, Chiang KC, Yeh TS. Prognostic Value of the Preoperative Neutrophil to Lymphocyte Ratio in Resectable Gastric Cancer. Medicine (Baltimore). 2015;94:e1589.

128. Inoue D, Ozaka M, Matsuyama M, Yamada I, Takano K, Saiura A, Ishii H. Prognostic value of neutrophillymphocyte ratio and level of C-reactive protein in a large cohort of pancreatic cancer patients: a retrospective study in a single institute in Japan. Jpn J Clin Oncol. 2015;45:61-66.

129. Ji WH, Jiang YH, Ji YL, Li B, Mao WM. Prechemotherapy neutrophil : lymphocyte ratio is superior to the platelet : lymphocyte ratio as a prognostic indicator for locally advanced esophageal squamous cell cancer treated with neoadjuvant chemotherapy. Dis Esophagus. 2015; 29:40311.

130. Kim EY, Lee JW, Yoo HM, Park CH, Song KY. The Platelet-to-Lymphocyte Ratio Versus Neutrophil-toLymphocyte Ratio: Which is Better as a Prognostic Factor in Gastric Cancer? Ann Surg Oncol. 2015;22:4363-4370.

131. Kim JH, Han DS, Bang HY, Kim PS, Lee KY. Preoperative neutrophil-to-lymphocyte ratio is a prognostic factor for overall survival in patients with gastric cancer. Ann Surg Treat Res. 2015;89:81-86.

132. Liao R, Tang ZW, Li DW, Luo SQ, Huang P, Du CY. Preoperative neutrophil-to-lymphocyte ratio predicts recurrence of patients with single-nodule small hepatocellular carcinoma following curative resection: a retrospective report. World J Surg Oncol. 2015;13:265.

133. Liu JS, Huang Y, Yang X, Feng JF. A nomogram to predict prognostic values of various inflammatory biomarkers in patients with esophageal squamous cell carcinoma. Am J Cancer Res. 2015;5:2180-2189.

134. Luo G, Guo M, Liu Z, Xiao Z, Jin K, Long J, Liu L, Liu C, Xu J, Ni Q, Yu X. Blood neutrophil-lymphocyte ratio predicts survival in patients with advanced pancreatic cancer treated with chemotherapy. Ann Surg Oncol. 2015;22:670-676.

135. Mori K, Toiyama Y, Saigusa S, Fujikawa H, Hiro J, Kobayashi M, Ohi M, Araki T, Inoue Y, Tanaka K, Mohri Y, Kusunoki M. Systemic Analysis of Predictive Biomarkers for Recurrence in Colorectal Cancer Patients Treated with Curative Surgery. Dig Dis Sci. 2015;60:24772487.

136. Nagai S, Mangus RS, Kubal CA, Ekser B, Fridell JA, Klingler KR, Maluccio MA, Tector AJ. Prognosis after recurrence of hepatocellular carcinoma in liver transplantation: predictors for successful treatment and survival. Clin Transplant. 2015;29:1156-1163.

137. Nagasaki T, Akiyoshi T, Fujimoto Y, Konishi T, Nagayama S, Fukunaga Y, Ueno M. Prognostic Impact of Neutrophilto-Lymphocyte Ratio in Patients with Advanced Low Rectal Cancer Treated with Preoperative Chemoradiotherapy. Dig Surg. 2015;32:496-503.

138. Neal CP, Cairns V, Jones MJ, Masood MM, Nana GR, Mann CD, Garcea G, Dennison AR. Prognostic performance of inflammation-based prognostic indices in patients with resectable colorectal liver metastases. Med Oncol. 2015;32:144.

139. Okamura Y, Ashida R, Ito T, Sugiura T, Mori K, Uesaka K. Preoperative neutrophil to lymphocyte ratio and prognostic nutritional index predict overall survival after hepatectomy for hepatocellular carcinoma. World J Surg. 2015;39:1501- 
1509.

140. Pine JK, Morris E, Hutchins GG, West NP, Jayne DG, Quirke P, Prasad KR. Systemic neutrophil-to-lymphocyte ratio in colorectal cancer: the relationship to patient survival, tumour biology and local lymphocytic response to tumour. Br J Cancer. 2015;113:204-211.

141. Qi Q, Geng Y, Sun M, Wang P, Chen Z. Clinical implications of systemic inflammatory response markers as independent prognostic factors for advanced pancreatic cancer. Pancreatology. 2015;15:145-150.

142. Qu JL, Qu XJ, Li Z, Zhang JD, Liu J, Teng YE, Jin B, Zhao MF, Yu P, Shi J, Fu LY, Wang ZN, Liu YP. Prognostic Model Based on Systemic Inflammatory Response and Clinicopathological Factors to Predict Outcome of Patients with Node-Negative Gastric Cancer. PLoS One 2015; 10:e0128540.

143. Qiu M, Zhou Y, Jin Y, Wei XL, Wang DS, Ren C, Bai L, Yang DJ, Xu RH. Prognostic effect of high pretreatment neutrophil to lymphocyte ratio on survival of patients with gastric adenocarcinoma in China. Int J Biol Markers. 2015;30:e96-103.

144. Racz JM, Cleghorn MC, Jimenez MC, Atenafu EG, Jackson TD, Okrainec A, Venkat Raghavan L, Quereshy FA. Predictive Ability of Blood Neutrophil-to-Lymphocyte and Platelet-to-Lymphocyte Ratios in Gastrointestinal Stromal Tumors. Ann Surg Oncol. 2015;22:2343-2350.

145. Seong MK. Prognostic Inflammation Score in Surgical Patients with Colorectal Cancer. J Korean Med Sci. 2015;30:1793-1799.

146. Shao Y, Ning Z, Chen J, Geng Y, Gu W, Huang J, Pei H, Shen Y, Jiang J. Prognostic nomogram integrated systemic inflammation score for patients with esophageal squamous cell carcinoma undergoing radical esophagectomy. Sci Rep. 2015;5:18811.

147. Shibutani M, Maeda K, Nagahara H, Ohtani H, Sakurai K, Yamazoe A, Kimura K, Toyokawa T, Amano R, Kubo N, Tanaka H, Muguruma K, Ohira M, et al. Significance of Markers of Systemic Inflammation for Predicting Survival and Chemotherapeutic Outcomes and Monitoring Tumor Progression in Patients with Unresectable Metastatic Colorectal Cancer. Anticancer Res. 2015;35:5037-5046.

148. Shibutani M, Maeda K, Nagahara H, Ohtani H, Iseki Y, Ikeya T, Sugano K, Hirakawa K. The prognostic significance of a postoperative systemic inflammatory response in patients with colorectal cancer. World J Surg Oncol. 2015;13:194.

149. Shin JS, Suh KW, Oh SY. Preoperative neutrophil to lymphocyte ratio predicts survival in patients with T1-2N0 colorectal cancer. J Surg Oncol. 2015;112:654-657.

150. Song A, Eo W, Lee S. Comparison of selected inflammation-based prognostic markers in relapsed or refractory metastatic colorectal cancer patients. World J Gastroenterol. 2015;21:12410-12420.

151. Spolverato G, Maqsood H, Kim Y, Margonis G, Luo
T, Ejaz A, Pawlik TM. Neutrophil-lymphocyte and platelet-lymphocyte ratio in patients after resection for hepato-pancreatico-biliary malignancies. J Surg Oncol 2015;111:868-874.

152. Sukato DC, Tohme S, Chalhoub D, Han K, Zajko A, Amesur N, Orons P, Marsh JW, Geller DA, Tsung A. The Prognostic Role of Neutrophil-to-Lymphocyte Ratio in Patients with Unresectable Hepatocellular Carcinoma Treated with Radioembolization. J Vasc Interv Radiol. 2015;26:816-824.e811.

153. Sun KY, Xu JB, Chen SL, Yuan YJ, Wu H, Peng JJ, Chen CQ, Guo P, Hao YT, He YL. Novel immunological and nutritional-based prognostic index for gastric cancer. World J Gastroenterol. 2015;21:5961-5971.

154. Tajiri K, Kawai K, Minemura M, Yasumura S, Hosokawa A, Kawabe H, Tomizawa G, Sugiyama T. Neutrophil/ lymphocyte ratio as a prognostic indicator of hepatic arterial infusion chemotherapy with arterial cisplatin plus continuous 5-fluorouracil. Hepatol Res. 2015;45:755-763.

155. Toiyama $\mathrm{Y}$, Inoue $\mathrm{Y}$, Kawamura $\mathrm{M}$, Kawamoto A, Okugawa Y, Hiro J, Saigusa S, Tanaka K, Mohri Y, Kusunoki M. Elevated platelet count as predictor of recurrence in rectal cancer patients undergoing preoperative chemoradiotherapy followed by surgery. Int Surg. 2015;100:199-207.

156. Wang Q, Blank S, Fiel MI, Kadri H, Luan W, Warren L, Zhu A, Deaderick PA, Sarpel U, Labow DM, Hiotis SP. The Severity of Liver Fibrosis Influences the Prognostic Value of Inflammation-Based Scores in Hepatitis B-Associated Hepatocellular Carcinoma. Ann Surg Oncol. 2015;22 Suppl 3:S1125-1132.

157. Wang W, Ye Y, Wang T, Zhang F, Geng L, Yu J, Zhou L, Yan S, Zheng S. Prognostic prediction of male recipients selected for liver transplantation: With special attention to neutrophil-lymphocyte ratio. Hepatol Res. 2016;46:899907.

158. Xiao GQ, Yang JY, Yan LN. Combined Hangzhou criteria with neutrophil-lymphocyte ratio is superior to other criteria in selecting liver transplantation candidates with HBVrelated hepatocellular carcinoma. Hepatobiliary Pancreat Dis Int. 2015;14:588-595.

159. Yu L, Lv CY, Yuan AH, Chen W, Wu AW. Significance of the preoperative neutrophil-to-lymphocyte ratio in the prognosis of patients with gastric cancer. World J Gastroenterol. 2015;21:6280-6286.

160. Zhou D, Zhang Y, Xu L, Zhou Z, Huang J, Chen M. A monocyte/granulocyte to lymphocyte ratio predicts survival in patients with hepatocellular carcinoma. Sci Rep. 2015;5:15263.

161. Alagappan M, Pollom EL, von Eyben R, Kozak MM, Aggarwal S, Poultsides GA, Koong AC, Chang DT. Albumin and Neutrophil-Lymphocyte Ratio (NLR) Predict Survival in Patients With Pancreatic Adenocarcinoma Treated With SBRT. Am J Clin Oncol. 2016. 
162. Asaoka T, Miyamoto A, Maeda S, Tsujie M, Hama N, Yamamoto K, Miyake M, Haraguchi N, Nishikawa K, Hirao M, Ikeda M, Sekimoto M, Nakamori S. Prognostic impact of preoperative NLR and CA19-9 in pancreatic cancer. Pancreatology. 2016;16:434-440.

163. Asari S, Matsumoto I, Toyama H, Shinzeki M, Goto T, Ishida J, Ajiki T, Fukumoto T, Ku Y. Preoperative independent prognostic factors in patients with borderline resectable pancreatic ductal adenocarcinoma following curative resection: the neutrophil-lymphocyte and plateletlymphocyte ratios. Surg Today. 2016;46:583-592.

164. Giampieri R, Maccaroni E, Mandolesi A, Del Prete M, Andrikou K, Faloppi L, Bittoni A, Bianconi M, Scarpelli M, Bracci R, Scartozzi M, Cascinu S. Mismatch repair deficiency may affect clinical outcome through immune response activation in metastatic gastric cancer patients receiving first-line chemotherapy. Gastric Cancer. 2017; 20:156-163.

165. Goh BK, Chok AY, Allen JC Jr, Quek R, Teo MC, Chow PK, Chung AY, Ong HS, Wong WK. Blood neutrophilto-lymphocyte and platelet-to-lymphocyte ratios are independent prognostic factors for surgically resected gastrointestinal stromal tumors. Surgery. 2016;159:11461156.

166. Haruki K, Shiba H, Horiuchi T, Shirai Y, Iwase R, Fujiwara Y, Furukawa K, Misawa T, Yanaga K. Neutrophil to Lymphocyte Ratio Predicts Therapeutic Outcome After Pancreaticoduodenectomy for Carcinoma of the Ampulla of Vater. Anticancer Res. 2016;36:403-408.

167. Hirahara N, Matsubara T, Hayashi H, Takai K, Nakada S, Tajima Y. Prognostic Importance of Controlling Nutritional Status in Patients Undergoing Curative Thoracoscopic Esophagectomy for Esophageal Cancer. Am J Ther. 2016.

168. Huang GQ, Zhu GQ, Liu YL, Wang LR, Braddock M, Zheng MH, Zhou MT. Stratified neutrophil-tolymphocyte ratio accurately predict mortality risk in hepatocellular carcinoma patients following curative liver resection. Oncotarget. 2016;7:5429-5439. doi: 10.18632/ oncotarget.6707.

169. Ishizuka M, Nagata H, Takagi K, Iwasaki Y, Shibuya N, Kubota K. Clinical Significance of the C-Reactive Protein to Albumin Ratio for Survival After Surgery for Colorectal Cancer. Ann Surg Oncol. 2016;23:900-907.

170. Ji F, Liang Y, Fu SJ, Guo ZY, Shu M, Shen SL, Li SQ, Peng BG, Liang LJ, Hua YP. A novel and accurate predictor of survival for patients with hepatocellular carcinoma after surgical resection: the neutrophil to lymphocyte ratio (NLR) combined with the aspartate aminotransferase/platelet count ratio index (APRI). BMC Cancer. 2016;16:137.

171. Jung J, Park SY, Park SJ, Park J. Prognostic value of the neutrophil-to-lymphocyte ratio for overall and diseasefree survival in patients with surgically treated esophageal squamous cell carcinoma. Tumour Biol. 2016;37:71497154.

172. Kishiki T, Masaki T, Mastuoka H, Abe N, Mori T,
Sugiyama M. New Prognostic Scoring System for Incurable Stage IV Colorectal Cancer. Asian Pac J Cancer Prev. 2016;17:597-601.

173. Kosumi K, Baba Y, Ishimoto T, Harada K, Nakamura K, Ohuchi M, Kiyozumi Y, Izumi D, Tokunaga R, Taki K, Higashi T, Miyata T, Kurashige J, et al. Neutrophil/ lymphocyte ratio predicts the prognosis in esophageal squamous cell carcinoma patients. Surg Today. 2016;46:405-413.

174. Lee BS, Lee SH, Son JH, Jang DK, Chung KH, Lee YS, Paik WH, Ryu JK, Kim YT. Neutrophil-lymphocyte ratio predicts survival in patients with advanced cholangiocarcinoma on chemotherapy. Cancer Immunol Immunother. 2016;65:141-150.

175. Lin G, Liu Y, Li S, Mao Y, Wang J, Shuang Z, Chen J. Elevated neutrophil-to-lymphocyte ratio is an independent poor prognostic factor in patients with intrahepatic cholangiocarcinoma. Oncotarget. 2016; 7:50963-50971. doi: 10.18632/oncotarget.7680.

176. Lu SD, Wang YY, Peng NF, Peng YC, Zhong JH, Qin HG, Xiang BD, You XM, Ma L, Li LQ. Preoperative Ratio of Neutrophils to Lymphocytes Predicts Postresection Survival in Selected Patients With Early or Intermediate Stage Hepatocellular Carcinoma. Medicine (Baltimore). 2016;95:e2722.

177. Park HS, Lee HS, Park JS, Lee DK, Lee SJ, Yoon DS, Lee MG, Jeung HC. Prognostic Scoring Index for Patients with Metastatic Pancreatic Adenocarcinoma. Cancer Res Treat. 2016; 48:1253-1263.

178. Takakura K, Ito Z, Suka M, Kanai T, Matsumoto Y, Odahara S, Matsudaira H, Haruki K, Fujiwara Y, Saito R, Gocho T, Nakashiro K, Hamakawa H, et al. Comprehensive assessment of the prognosis of pancreatic cancer: peripheral blood neutrophil-lymphocyte ratio and immunohistochemical analyses of the tumour site. Scand J Gastroenterol. 2016;51:610-617.

179. Turner N, Wong HL, Templeton A, Tripathy S, Whiti Rogers T, Croxford M, Jones I, Sinnathamby M, Desai J, Tie J, Bae S, Christie M, Gibbs P, et al. Analysis of local chronic inflammatory cell infiltrate combined with systemic inflammation improves prognostication in stage II colon cancer independent of standard clinicopathologic criteria. Int J Cancer. 2016;138:671-678.

180. Xie X, Luo KJ, Hu Y, Wang JY, Chen J. Prognostic value of preoperative platelet-lymphocyte and neutrophillymphocyte ratio in patients undergoing surgery for esophageal squamous cell cancer. Dis Esophagus. 2016;29:79-85.

181. Zhang F, Chen Z, Wang P, Hu X, Gao Y, He J. Combination of platelet count and mean platelet volume (COP-MPV) predicts postoperative prognosis in both resectable early and advanced stage esophageal squamous cell cancer patients. Tumour Biol. 2016; 37:9323-31. 